\title{
Protein and Signaling Networks in Vertebrate Photoreceptor Cells
}

\author{
Karl-Wilhelm Koch ${ }^{1 *}$ and Daniele Dell'Orco ${ }^{2}$ \\ ${ }^{1}$ Department of Neurosciences, Biochemistry Group, University of Oldenburg, Oldenburg, Germany, ${ }^{2}$ Department of \\ Neurological, Biomedical and Movement Sciences, Section of Biological Chemistry and Center for BioMedical Computing \\ (CBMC), University of Verona, Verona, Italy
}

Vertebrate photoreceptor cells are exquisite light detectors operating under very dim and bright illumination. The photoexcitation and adaptation machinery in photoreceptor cells consists of protein complexes that can form highly ordered supramolecular structures and control the homeostasis and mutual dependence of the secondary messengers cyclic guanosine monophosphate (cGMP) and $\mathrm{Ca}^{2+}$. The visual pigment in rod photoreceptors, the $\mathrm{G}$ protein-coupled receptor rhodopsin is organized in tracks of dimers thereby providing a signaling platform for the dynamic scaffolding of the $G$ protein transducin. Illuminated rhodopsin is turned off by phosphorylation catalyzed by rhodopsin kinase (GRK1) under control of $\mathrm{Ca}^{2+}$-recoverin. The GRK1 protein complex partly assembles in lipid raft structures, where shutting off rhodopsin seems to be more effective. Re-synthesis of cGMP is another crucial step in the recovery of the photoresponse after illumination. It is catalyzed by membrane bound sensory guanylate cyclases (GCs) and is regulated by specific neuronal $\mathrm{Ca}^{2+}$-sensor proteins called guanylate cyclase-activating proteins (GCAPs). At least one GC (ROS-GC1) was shown to be part of a multiprotein complex having strong interactions with the cytoskeleton and being controlled in a multimodal $\mathrm{Ca}^{2+}$-dependent fashion. The final target of the cGMP signaling cascade is a cyclic nucleotide-gated (CNG) channel that is a hetero-oligomeric

Edited by:

Jean-Marc Taymans, UMR1172, Jean-Pierre Aubert Research Center, France

Reviewed by: Alexander Dizhoor, Salus University, USA Johann Helmut Brandstätter, FAU Erlangen-Nuremberg, Germany

*Correspondence: Karl-Wilhelm Koch karl.w.koch@uni-oldenburg.de

Received: 25 September 2015 Accepted: 26 October 2015 Published: 17 November 2015

Citation: Koch K-W and Dell'Orco D (2015) Protein and Signaling Networks in Vertebrate Photoreceptor Cells.

Front. Mol. Neurosci. 8:67. doi: 10.3389/fnmol.2015.00067 protein located in the plasma membrane and interacting with accessory proteins in highly organized microdomains. We summarize results and interpretations of findings related to the inhomogeneous organization of signaling units in photoreceptor outer segments.

Keywords: multi-protein complexes, second messenger signaling, phototransduction, cGMP, calcium-binding proteins

\section{INTRODUCTION}

Vertebrate photoreceptor cells are neurosensory cells of unique morphology and specialized function. They are divided into two general types, rods and cones, which mediate vision at night and daylight, respectively. Absorption of photons by visual pigments, rhodopsin in rods and cone opsins in cones, triggers a well understood signaling cascade that has been thoroughly investigated in the past decades. Numerous articles in the last decades have therefore summarized the basic features of the phototransduction process (e.g., Stryer, 1991; Kaupp and Koch, 1992; Koch, 1994; Pugh and Lamb, 2000; Luo et al., 2008; Wensel, 2008; Arshavsky and Burns, 2012; Korenbrot, 2012; Palczewski, 2012): coupling of visual pigments to the heterotrimeric G protein transducin, activation of the effector phosphodiesterase PDE6 by the $\mathrm{G}$ protein and efficient hydrolysis of the second messenger cyclic nucleotide guanosine $3^{\prime}, 5^{\prime}$ cyclic monophosphate (cGMP) with high turnover rates, regulation of the cyclic nucleotide-gated 
(CNG)-channel by cGMP and re-synthesis of cGMP by a guanylate cyclase (GC) complex that is controlled by a powerful $\mathrm{Ca}^{2+}$-dependent feedback loop (Dizhoor et al., 2010; Koch et al., 2010). The cytoplasmic $\mathrm{Ca}^{2+}$-concentration in the outer segments of photoreceptor cells is maintained by two transport routes: $\mathrm{Ca}^{2+}$-influx through the $\mathrm{CNG}$-channel and $\mathrm{Ca}^{2+}$-extrusion by $\mathrm{Na}^{+/} \mathrm{Ca}^{2+}, \mathrm{K}^{+}$-exchanger. Due to the lightdependent closure of the CNG-channel (Kaupp and Seifert, 2002), $\mathrm{Ca}^{2+}$ cannot enter the cell, but is expelled via the exchanger leading to a net decrease in cytoplasmic $\mathrm{Ca}^{2+}$. Termination of the signaling cascade is an equally critical step for the precise formation of light responses and photoresponse recovery. All activation steps of the excitation pathway need efficient shut-off mechanisms (Burns, 2010). Thus, rhodopsin is phosphorylated by rhodopsin kinase (GRK1) under control of $\mathrm{Ca}^{2+}$ /recoverin (Senin et al., 2002b) and competitive binding of arrestin to phospho-rhodopsin prevents further interaction of transducin with rhodopsin (Sommer et al., 2014). As regards the effector, the acceleration of the intrinsic GTPase activity of transducin by RGS9-1 and accessory proteins G $\beta 5 \mathrm{~L}$ and R9AP leads to a sub-second deactivation of transducin (Wensel, 2008), which in turns dissociates from PDE6, thus restoring the low basal activity controlled by its small inhibitory $\gamma$ subunits. Figure 1 summarizes the basic features of the phototransduction cascade.

The detailed knowledge about the physiology and biochemistry of phototransduction has been covered in

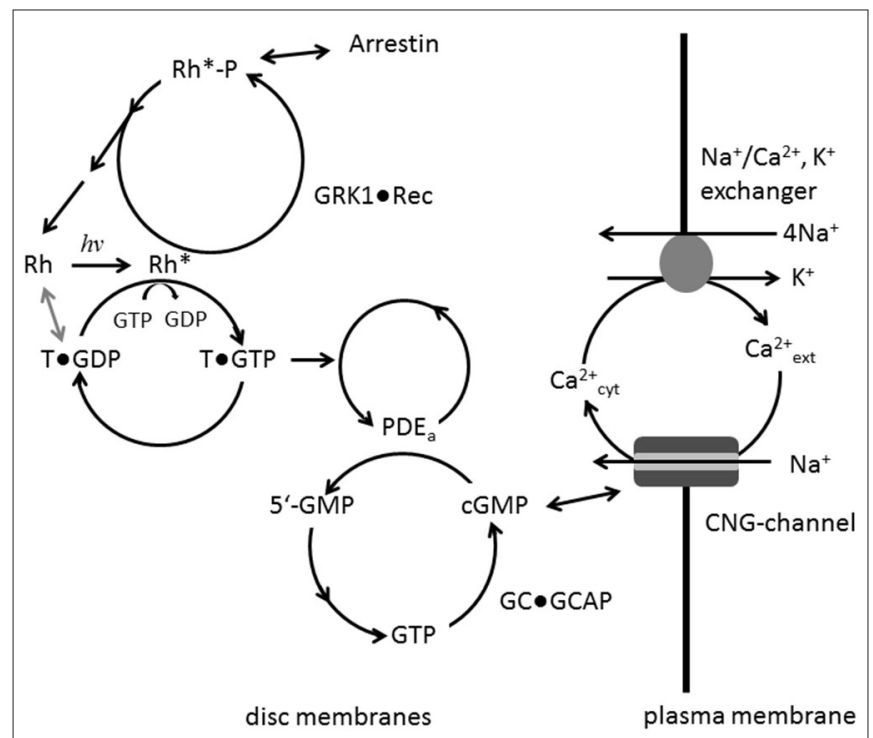

FIGURE 1 | Main signaling steps in phototransduction. Photo-activation of rhodopsin (Rh to $\mathrm{Rh}^{*}$ ) leads to GDP/GTP exchange at the G protein transducin (T) which in turn activates its effector PDE. Hydrolysis of cGMP is catalyzed by activated PDE; resynthesis of cGMP by guanylate cyclase (GC) is under control of a negative $\mathrm{Ca}^{2+}$-feedback involving the GC-activating proteins (GCAP) $\mathrm{Ca}^{2+}$-sensor proteins. $\mathrm{Ca}^{2+}$ enters the cell via the cyclic nucleotide-gated (CNG)-channel and is extruded by the exchanger. Rh* is phosphorylated by GRK1, when inhibition by $\mathrm{Ca}^{2+}$-bound recoverin is relieved. Arrestin can bind to phosphorylated Rh* preventing further activation of transducin. numerous in-depth reviews (for a small selection see references above). The present article, however will address issues, which had been investigated in more recent years showing that the photoreceptor outer segment is not a well-stirred compartment, but appears rather inhomogeneous. Publications indicating different aspects of heterogeneity date back several decades, but have been mainly interpreted as signs of the natural ageing and renewal process in outer segments. For example, gradients along the longitudinal axis of outer segments have been described for second messenger molecules (Leibovic and Bandarchi, 1997a,b; Gray-Keller et al., 1999), disc membrane composition (Boesze-Battaglia et al., 1989, 1990; Boesze-Battaglia and Albert, 1990), light response variation (Baylor and Lamb, 1982; Schnapf, 1983; Mazzolini et al., 2015) and enzymatic reactions (Shichi and Williams, 1979). While the ageing process is out of question the physiological consequences of gradients of intracellular components and the heterogeneous formation of multi-protein units come into focus. Proteins of the photoexcitation and adaptation machinery are assembled in complexes that can form highly ordered supramolecular structures by interacting with the supporting disc membrane vesicles (Wensel, 2008). Moreover, some of the main molecular components of the phototransduction cascade have been found to be involved in other non-visual related signaling networks (Kiel et al., 2011). Thus, we will discuss in the present review how these signal transducing modules contribute to the efficient and precise processing of light signals. We have restricted our review to rod biochemistry and physiology, since knowledge about cones and about protein and signaling networks in cones is less advanced. Moreover, it is worth noting that some aspects concerning for example the supramolecular organization of rhodopsin (see below) have not been investigated yet for the cone system so far.

\section{PHOTORESPONSE GRADIENT ALONG THE LONGITUDINAL AXIS OF PHOTORECEPTOR OUTER SEGMENTS}

Suction electrode recordings from amphibian rods showed already in the 1980s that single flash response kinetics are slower when the cell is illuminated at the tip of the rod outer segment than at the base. Response amplitudes become smaller the farther away from the base the flash is delivered (Schnapf, 1983). Outer segments are renewed every 10 days in mammalians and 6-7 weeks in amphibians by a process called disc shedding, in which the disc components at the tip of the outer segments are phagocytized by the retinal pigment epithelium (Young, 1967). This process keeps the length of the outer segment constant under physiological conditions and the heterogeneity of flash response kinetics and amplitudes were interpreted as the results of an ageing process. Mazzolini et al. (2015) have recently confirmed and extended these earlier observations using dissociated rods from adult male Xenopus laevis frogs. However, their analysis showed that the amplitude of saturating and single photon responses decreased by $5-10$ times, when illumination of the tip is compared with that of the base. Previous recordings showed only a twofold 
difference in sensitivity. Mazzolini et al. (2015) excluded a lower probability of photon capture by rhodopsin, but instead suggested that a reduced amplification of the transduction cascade leads to a reduction in efficacy due to a progressive depletion of PDE6 along the longitudinal axis of rod outer segment. Further, the kinetic variability of the light responses at the base, middle and tip of the outer segment is not contemplated by the existing quantitative models, which operate under the assumption that the biochemical components of the transduction machinery are more or less uniformly distributed (Hamer et al., 2005; Bisegna et al., 2008; Dell'Orco et al., 2009; Shen et al., 2010). Instead, the authors suggest a "series of interconnected compartments" that might have different local concentrations of key factors and therefore vary in their responsiveness to light.

\section{SUPRAMOLECULAR ORGANIZATION OF RHODOPSIN}

Efficient photon capture by photoreceptor cells is due to the high density of the visual pigment rhodopsin in stacks of disc membranes reaching $\geq 25,000 \mu \mathrm{m}^{-2}$. Work from the early 1970 s came to the conclusion that rhodopsin is homogenously distributed in disc membranes and can laterally diffuse without much restriction (Cone, 1972; Liebman and Entine, 1974; Poo and Cone, 1974). This concept of random distribution and free diffusion in the membrane was further supported by results obtained by neutron diffraction and electron microscopy (Saibil et al., 1976; Roof and Heuser, 1982). After being accepted in the field for 30 years this "classical" view was challenged by an atomic force microscopy (AFM) study of disc membranes, which showed in 2003 that rhodopsin dimers are found in a paracrystalline arrangement suggesting a lower degree of lateral diffusion (Fotiadis et al., 2003a, 2004). Subsequent studies were in agreement with a more inhomogeneous distribution of immobile rhodopsin fractions (Govardovskii et al., 2009). Another very recent independent AFM study revealed that dimers of rhodopsin are organized in nanodomains, whose supramolecular features seem to be conserved in humans and mice. For example, the discs diameter was found to depend on the number of rhodopsin molecules embedded in the membrane, however it was found to be independent of rhodopsin's spatial density (Whited and Park, 2015). A different study further reported highly concentrated patches of rhodopsin in the central region of a disc. No rhodopsin was located near the rim region that was occupied by peripherin and Rom proteins, which are well established marker proteins for this region of the outer segment (Buzhynskyy et al., 2011).

Very recently, using cryosections of dark-adapted intact rod photoreceptors from mice Gunkel et al. (2015) demonstrated by cryoelectron tomography the presence of tracks of rhodopsin dimers. In a scenario only partly similar to previous AFM determinations, the authors observed that at least ten rhodopsin dimers form a row, rows form pairs (tracks), and tracks are aligned parallel to the disc incisures, with profound implications for the kinetics of phototransduction.
Soon after the classical view of randomly distributed and freely diffusing rhodopsin monomers was challenged, a controversial discussion on this topic started and had not ended so far (Chabre et al., 2003; and reply by Fotiadis et al., 2003b). Previous biochemical and biophysical studies demonstrated that monomeric rhodopsin is sufficient to activate transducin, leading to the conclusion that no mechanistic need for a rhodopsin dimer exists (Chabre and le Maire, 2005; Ernst et al., 2007). Biochemical studies of detergent solubilized rhodopsin however provided evidence for the existence of rhodopsin dimers or oligomers depending on the detergent and solubilization conditions (Jastrzebska et al., 2004). But the use of detergents is prone to affect the quaternary structure of proteins and was therefore considered as a weak argument to support the existence of higher order organization rhodopsin in disc membranes (Chabre and le Marie, 2004). The paracrystalline arrangement of rhodopsin dimers observed in the early AFM studies was interpreted as the results of separation of the lipid phase from proteins at low temperatures (Chabre et al., 2003), but the higher order topography was also observed at room temperature (Fotiadis et al., 2003b), moreover recent AFM determinations confirmed that higher order nano-domains of rhodopsin are found both in mice and humans (Whited and Park, 2015).

A very recent study investigated the nature of rhodopsin dimers by showing that peptides encompassing the transmembrane domains (TMs) of rhodopsin block its dimerization both in vitro and in living cells, without however affecting the rates of transducin activation (Jastrzebska et al., 2015). This suggests that the supramolecular organization of rhodopsin could be essential for the stabilization of rod outer segments and receptor trafficking rather than for activating the G protein.

\section{DYNAMICS OF TRANSIENT PROTEIN COMPLEXES INVOLVING RHODOPSIN}

The supramolecular organization of nearly immobile rhodopsin imposes a conceptual problem on the mechanistic understanding of the phototransduction cascade, which operates on a millisecond time base with high sensitivity. Intuitively one might predict that arrays of paracrystalline rhodopsin would slow down the activation kinetics. The investigation of how the diffusion properties of rhodopsin and transducin are affected by specific supramolecular assemblies is not trivial, and has so far been investigated only by computational analyses that incorporate available experimental data. Results were not always intuitive, because rhodopsin supramolecular assemblies and molecular crowding in discs imply anomalous and anisotropic diffusion paths for peripheral membrane proteins such as transducin, which significantly differ from the classical free diffusion case. In a first approach to the problem, Monte Carlo simulations of rhodopsin-transducin encounters in both the classical free diffusion and emerging paracrystalline rafts scenarios suggested that an unexpected favorable effect on the temporal response of early phototransduction reactions may occur, if rhodopsin molecules were packed in highly ordered assemblies 
(Dell'Orco and Schmidt, 2008). Moreover, recent surface plasmon resonance studies (Dell'Orco and Koch, 2011) performed with detergent solubilized native rhodopsin demonstrated the existence of a protein-protein interaction between dark-adapted rhodopsin and transducin, which was postulated earlier based on the analysis of their structural complementarity (Fanelli and Dell'Orco, 2005; Dell'Orco et al., 2007). Dark rhodopsin-transducin binding occurs with submicromolar affinity and is characterized by very fast association and dissociation rates in a "dynamic scaffolding" frame, where concerted diffusion/binding phenomena give rise to a dynamic hopping of transducin on rhodopsin supramolecular assemblies (Dell'Orco and Koch, 2011). The transient precoupling step was integrated into the framework of phototransduction models of both amphibian and murine rods, and was found to be compatible with the overall cascade kinetics (Invergo et al., 2014; Dell'Orco, 2015). The physiological presence of rhodopsin-transducin transient complexes has been somewhat questioned and debated (Schöneberg et al., 2014, 2015; Dell'Orco and Koch, 2015), however it appears now quite clear that it may have deep implications for the capability of rods to detect single photons (Cangiano and Dell'Orco, 2013; Dell'Orco, 2013), and seems to be an essential mechanistic step in the recently emerged picture of rhodopsin tracks observed by cryoelectron tomography, in order to create the "kinetic traps": owing to the frequent, rapid formation and breakup of precomplexes, transducin molecules could scan a rhodopsin track by discrete hopping events, resulting in an activation rate that, in the single-photon regime, would be determined by the number of the preassembled transducin molecules per track rather than the photoactivated rhodopsin lifetime. The number of transducin molecules activated per photoactivated rhodopsin would be therefore of the same order as the number of preassembled transducin molecules per unit track (Gunkel et al., 2015). The concepts developed in the last years in opposition to the "fluid mosaic" classical organization of the disc membrane have built up a novel structural picture of the early mechanisms triggering phototransduction, whose supramolecular features are summarized in Figure 2.

Proteomic profiling and protein network analysis of outer segments led to the prediction of signaling and/or trafficking pathways in addition to the activation and deactivation pathways that govern photoreceptor excitation and recovery. An important level of regulation of such alternative pathways seems to be played by small GTPases (Kiel et al., 2011). The monomeric G-protein Racl is among the putative binding partners of rhodopsin (Balasubramanian and Slepak, 2003), but its lower cellular concentration $(\sim 100$-fold excess of rhodopsin) and its medium affinity for rhodopsin (apparent $\mathrm{K}_{\mathrm{D}}=1.3 \mu \mathrm{M}$ ) would not allow a significant competition with the binding of transducin (Köster et al., 2014). However, under strong illumination, when transducin is depleted from the outer segment by transport to the inner segment (Pulvermüller et al., 2002; Sokolov et al., 2002; Lobanova et al., 2007), only about $10 \%$ of all rhodopsin molecules could form a complex with Rac1. Therefore, it is more likely that Rac1 binds to rhodopsin during transport after protein biosynthesis.

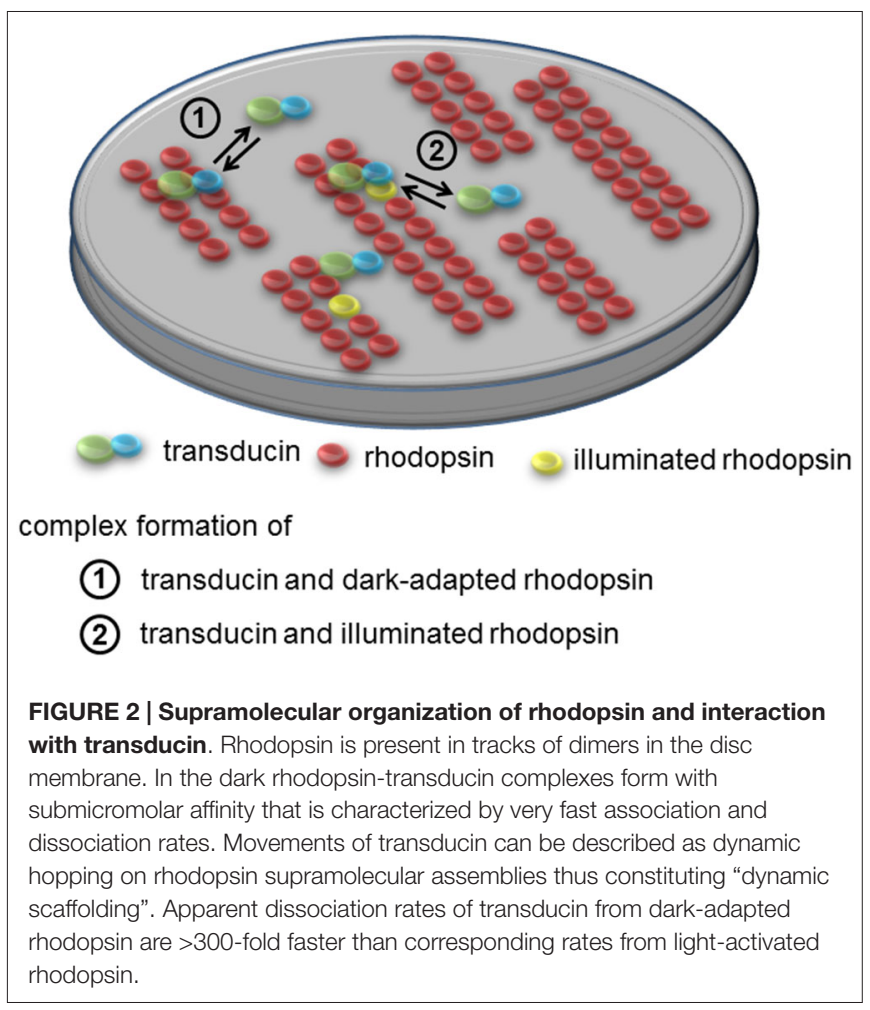

Intracellular trafficking, in particular under conditions of changing illumination has attained increasing interest in the photoreceptor research community. In order to keep this review focused we will not discuss this field in depth, but will refer to some reviews on this topic (Calvert et al., 2006; Karan et al., 2010; Pearring et al., 2013; Wang and Deretic, 2014).

\section{DEACTIVATION OF RHODOPSIN}

The efficient shut-off of the phototransduction cascade requires as initial step the deactivation of photoactivated rhodopsin. This crucial step is performed by the interplay of several proteins and binding events: GRK-1 phosphorylates illuminated rhodopsin at its C-terminus (Maeda et al., 2003), which allows subsequent binding of arrestin ( $\mathrm{p} 48)$ or the arrestin splice variant $\mathrm{p} 44$ (Granzin et al., 2012; Kim et al., 2013). Binding of arrestin to phosphorylated rhodopsin prevents further activation of transducin (Pulvermüller et al., 1993).

Serine and threonine residues present in the C-terminus of rhodopsin within the amino acid positions 324-348 are potential sites for phosphorylation by GRK1. Like other members of the GRK family, GRK1 phosphorylates only the lightstimulated (bleached) form of the receptor and does not act upon the unbleached receptor (for reviews, see Senin et al., 2002b; Maeda et al., 2003; Premont and Gainetdinov, 2007). Activity of GRK1 is under control of a $\mathrm{Ca}^{2+}$-dependent negative feedback loop, but GRK1 itself is not sensitive to $\mathrm{Ca}^{2+}$. Changes in intracellular $\left[\mathrm{Ca}^{2+}\right]$ are sensed by retina specific neuronal $\mathrm{Ca}^{2+}$-sensor proteins including the 
$\mathrm{Ca}^{2+}$-binding protein recoverin (Senin et al., 2002b). By interacting with GRK1 in a $\mathrm{Ca}^{2+}$-dependent manner it controls GRK1 enzyme activity (Kawamura, 1993; Gorodovikova et al., 1994; Klenchin et al., 1995). Recoverin is heterogeneously acylated at its $\mathrm{N}$-terminus by an $\mathrm{N}$-myristoyl-transferase like activity (Dizhoor et al., 1992). When acylated recombinant forms of recoverin are investigated, a myristoyl group is routinely attached to the protein by co-expression of a $\mathrm{N}$-myristoyltransferase. The myristoyl moiety has a strong impact on the structural and functional properties of recoverin. For example, in the absence of $\mathrm{Ca}^{2+}$, the myristoyl group is buried within a hydrophobic pocket of the protein (Tanaka et al., 1995). Binding of $\mathrm{Ca}^{2+}$ to recoverin triggers a conformational change that leads to exposure of the myristoyl group and the hydrophobic pocket (Zozulya and Stryer, 1992; Ames et al., 1997), which facilitates its association with biological membranes and inhibition of GRK1 (Chen et al., 1995; Senin et al., 1995). Since the cytoplasmic $\mathrm{Ca}^{2+}$-concentration is high in the resting dark state of the photoreceptor cell, $\mathrm{Ca}^{2+}$-loaded recoverin associates with the disc membranes, interacts with GRK1 and inhibits its activity. Decrease of intracellular $\mathrm{Ca}^{2+}$ after illumination triggers dissociation of recoverin from the membranes and from GRK1

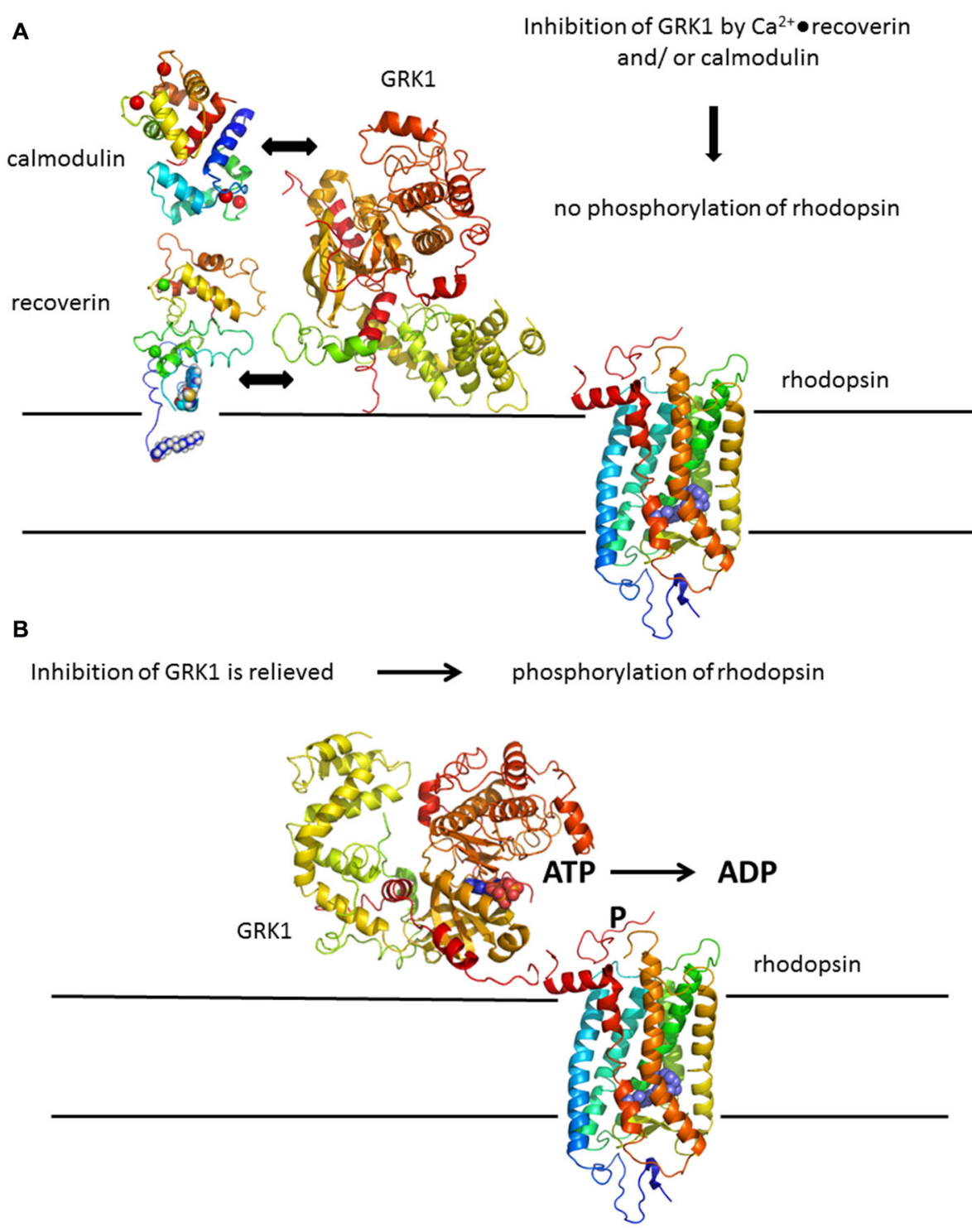

FIGURE 3 | Rhodopsin phosphorylation by GRK1. (A) Deactivation of rhodopsin is under control of a $\mathrm{Ca}^{2+}$-feedback loop involving Ca ${ }^{2+}$-sensor proteins recoverin and calmodulin. Both $\mathrm{Ca}^{2+}$-binding proteins have non-overlapping binding sites in GRK1 and act in a synergetic mode, for example by increasing the $\mathrm{Ca}^{2+}$-sensitivity of GRK1 regulation. (B) Inhibition of GRK1 is relieved at decreasing $\mathrm{Ca}^{2+}$-concentration after illumination leading to phosphorylation of rhodopsin. Structures were prepared with pymol; corresponding PDB codes are: 1 F88 for rhodopsin (Palczewski et al., 2000); 3 C51 for GRK1 (Singh et al., 2008); 1JSA for recoverin (Ames et al., 1997); 1CDM for calmodulin (Meador et al., 1993). 
thereby stopping the inhibition of GRK1 and allowing rhodopsin phosphorylation (Figures 3A,B).

The $\mathrm{Ca}^{2+}$-myristoyl switch of recoverin (Zozulya and Stryer, 1992) is prototypical for a variety of myristoylated proteins and has served as a benchmark for studying related switching mechanisms in other $\mathrm{Ca}^{2+}$-sensors (O'Callaghan et al., 2003; Li et al., 2011; Lim et al., 2011, 2014; Burgoyne and Haynes, 2015; Marino et al., 2015; Sulmann et al., 2015) or by characterizing the biocompatibility of nanoparticles (Marino et al., 2014). The $\mathrm{Ca}^{2+}$-binding and switching process in recoverin had been investigated in more detail by comparing WT recoverin with mutants containing disabled EF-hands or a truncated C-terminus (Senin et al., 2002a, 2003; Weiergräber et al., 2003, 2006). These studies revealed critical steps in sequential $\mathrm{Ca}^{2+}$-binding and defined crucial regions that control the $\mathrm{Ca}^{2+}$-sensitive regulation of GRK1. Several studies were also focused on regulatory aspects of GRK1 using sitedirected mutagenesis, pull down methods, SPR spectroscopy and rhodopsin phosphorylation assays (Huang et al., 2009, 2011; Komolov et al., 2009; Zernii et al., 2011; Orban et al., 2012). The N-terminus of GRK1 forms an amphipathic $\alpha$-helix, of which the first 25 amino acid residues interact with an exposed hydrophobic groove in recoverin (Ames et al., 2006; Higgins et al., 2006). A combination of structural analysis and computational modeling of the recoverin-kinase complex revealed that the protein-protein interface involves also the C-terminus of recoverin by forming a cation- $\pi$ interaction pair, which is essential for GRK1 target recognition by recoverin (Zernii et al., 2011). Fine-tuning of $\mathrm{Ca}^{2+}$-dependent regulation of GRK1 is further achieved by synergetic action of calmodulin (Figure 3A), which binds to a region in GRK1 distant from the recoverin binding site (Grigoriev et al., 2012).

Recent electrophysiological recordings on transgenic mice lacking recoverin $\left(\mathrm{Rv}^{-/-}\right)$showed shortened light responses indicating a reduced lifetime of light-activated rhodopsin (Makino et al., 2004; Bush and Makino, 2006; Chen et al., 2010), which is consistent with an inhibition of GRK1 by recoverin at high $\left[\mathrm{Ca}^{2+}\right]$. The same effect was recently observed by intra ocular and ex-vivo retinal delivery of liposomes loaded with recombinant recoverin or its antibody, which showed effects comparable to recoverin overexpression and downregulation, respectively (Asteriti et al., 2015). Similarly, overexpression of GRK1 in transgenic mice (12-fold higher than in wildtype (WT) mice) also leads to shortened light responses (Chen et al., 2012). By investigating mice harboring different genetic manipulations Chen et al. (2012) challenged previous investigations on mice expressing GRK1 at lower and higher levels than WT (Sakurai et al., 2011) and postulated a time constant of rhodopsin deactivation of about $50 \mathrm{~ms}$. In a different approach using bottom-up modeling, the rate limiting steps in the recovery of rods after illumination were investigated by simulating conditions, in which the expression levels of GRK1 and recoverin were altered individually or in combination (Invergo et al., 2013). The analysis provided a mechanistic explanation for the puzzling evidence that GRK1 over expression does not influence the saturation time of rods under bright light stimulation (Krispel et al., 2006; Sakurai et al., 2011), indeed attributing a compensating effect to arrestin oligomerization (Invergo et al., 2013). The recoverinGRK1 complex in cones is operating under dim light, but not in bright light demonstrating significant differences in the response recovery between rod and cone physiology (Sakurai et al., 2015). Very recently, Chen et al. (2015) suggested that GRK1 and recoverin participate in the activity regulation of PDE6, but biochemical evidence to support this hypothesis is lacking so far.

\section{SIGNALING MODULES AND LIPID RAFTS}

Patches of rhodopsin seen in AFM images (see above) were interpreted as lipid raft structures and biochemical fractionation studies pointed to the existence of lipid rafts in rod outer segments. Detergent resistant membranes or lipid rafts can be isolated from sucrose step gradients of cell suspensions that are solubilized with a low concentration of the nonionic detergent Triton X-100. Main features of lipid rafts are high cholesterol content, saturated fatty acids, glycolipids and the marker protein caveolin (Martin et al., 2005; Elliott et al., 2008) that was shown to co-localize with signaling proteins like transducin in rod outer segments (Elliott et al., 2003). In fact, whole signaling units have been identified in isolated lipid rafts from preparations of rod outer segments. For example, rhodopsin, transducin, its effector cGMP-phosphodiesterase, the shorter splice variant of arrestin p44 and the RGS9-G $35 \mathrm{~L}$ complex translocate to raft structures in a light-dependent manner (Seno et al., 2001; Nair et al., 2002; Balasubramanian and Slepak, 2003; Liu et al., 2003). Main conclusions from these studies were that the rhodopsin-transducin coupling is reduced and that phototransduction is less efficient in lipid micro-domains. Raft-specific protein complexes including rhodopsin were also suggested to have a role in the formation of outer segments (Berta et al., 2011).

Interestingly, relative protein composition of the raft fraction from rod outer segments was not only dependent on illumination, but also on the free $\mathrm{Ca}^{2+}$-concentration (Senin et al., 2004). Changing free $\mathrm{Ca}^{2+}$ causes proteins to translocate between the soluble fraction and the detergent resistant membrane fraction. Manipulation of the cholesterol content by the reagent methyl- $\beta$-cyclodextrin showed a clear dependence of recoverin controlled GRK1 activity: the $\mathrm{Ca}^{2+}$. dependent activity profile of GRK1 is shifted to higher $\mathrm{Ca}^{2+}$, when cholesterol is low and to lower $\mathrm{Ca}^{2+}$, when cholesterol is high (Senin et al., 2004). In native cells cholesterol is not homogeneously distributed in outer segment disc membranes, but instead rod outer segments contain a cholesterol gradient (high to low) from the base to the tip (Boesze-Battaglia et al., 1989, 1990; Boesze-Battaglia and Albert, 1990). This means, in terms of the cell's physiology, that rhodopsin shut-off by phosphorylation would be more effective at the base than at the tip leading to faster deactivation kinetics at the base. It remains an open question, whether the photoresponse gradient along the longitudinal axis (see above) results from a lipid raft gradient. If this were the case, the photoresponse gradient 
would in fact depend on the local supramolecular assembly of phototransduction components.

\section{GC PROTEIN COMPLEX}

In addition to signaling proteins that translocate to raft structures in a light-dependent manner, the membrane bound GC in photoreceptor cells is associated with rafts independent of the illumination conditions. This membrane bound sensory GC is expressed in two forms in vertebrate rod and cone cells (Dizhoor et al., 1994; Goraczniak et al., 1994; Lowe et al., 1995) and association of one form, presumably ROS-GC1 (synonymously named GC-E or RetGC1), had been detected by immunoblotting in detergent resistant membrane fractions (Nair et al., 2002; Senin et al., 2004). It is known, however from previous studies that GC activities co-fractionate with axonemes (Fleischmann and Denisevich, 1979) of rod cells and purification of the enzyme to an apparent homogeneity of a protein band at $110-112 \mathrm{kDa}$ is achieved by detergent/high salt extraction from Triton $\mathrm{X}$ 100 insoluble pellets (Hayashi and Yamazaki, 1991; Koch, 1991; Margulis et al., 1993). Association with cytoskeletal structures was also demonstrated by direct interaction studies showing co-immunoprecipitation of ROS-GC1 and tubulin (Schrem et al., 1999) and binding of actin (Hallett et al., 1996) to the cyclase (Figure 4 of GC signaling complex). Based on translocation studies on mice lacking ROS-GC1 $\left(\mathrm{GC}-\mathrm{E}^{-/-}\right)$it was suggested that ROS-GC1 is crucial for the intracellular trafficking of peripheral membrane proteins (Baehr et al., 2007; Karan et al., 2010). A co-immunoprecipitation study showed further that ROS-GC1 and the $\alpha$-subunit of transducin form a complex, which might regulate the lightdependent translocation of transducin (Rosenzweig et al., 2009).

Both GCs are regulated by $\mathrm{Ca}^{2+}$-sensor proteins (Koch and Stryer, 1988) named GC-activating proteins (GCAP) that detect changes in cytoplasmic $\mathrm{Ca}^{2+}$ via their $\mathrm{EF}$ hand $\mathrm{Ca}^{2+}$-binding motifs (Palczewski et al., 1994; Dizhoor et al., 1995; Frins et al., 1996). Guanylate cyclase-activating proteins (GCAPs) interact with the target GC at low and high $\mathrm{Ca}^{2+}$-concentration, although the binding affinity is not very high. Apparent affinity constants are in the lower micromolar to submicromolar range, which would allow transitory and flexible complex formation (Hwang and Koch, 2002; Peshenko et al., 2004, 2011a). Binding or dissociation of $\mathrm{Ca}^{2+}$ triggers conformational changes in GCAPs causing probably a rearrangement of the whole complex to increase or decrease GC activities (Sokal et al., 1999a; Hwang et al., 2001; Lim et al., 2009; Sulmann et al., 2014; Marino et al., 2015), which are high at low $\mathrm{Ca}^{2+}$ (and having $\mathrm{Mg}^{2+}$-bound in exchange for $\mathrm{Ca}^{2+}$; Peshenko and Dizhoor, 2006) and are low or even suppressed at saturating $\mathrm{Ca}^{2+}$-concentration. GCAPs are expressed in different isoforms from two or three in mammals to six or eight in teleost fish (Imanishi et al., 2004; Rätscho et al., 2009; Scholten and Koch, 2011; Fries et al., 2012). Expression of two or more isoforms in one cell type has raised questions as to the physiological meaning.

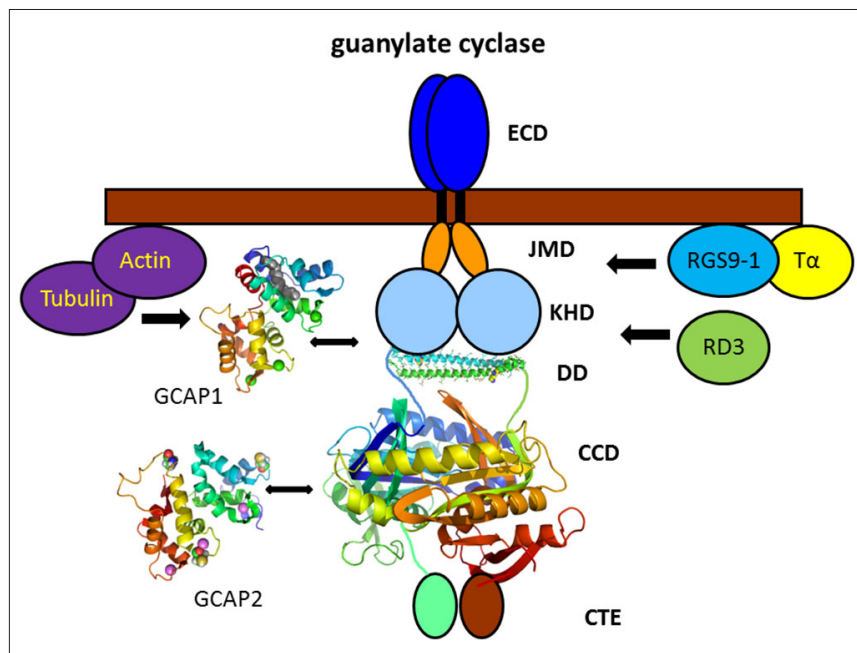

FIGURE 4 | Vertebrate photoreceptor GC and interacting proteins. Photoreceptor GCs contain several domains denoted as extracellular domain (ECD, which in rod outer segment is present in the intradiscal lumen; TM, transmembrane domain; JMD, juxtamembrane domain; KHD, kinase homology domain; DD, dimerization domain; CCD, cyclase catalytic domain; and CTE, a C-terminal extension). The tertiary structure of the DD and CCD is adapted from the solved three-dimensional structure of soluble GCs (Ma et al., 2010; Allerston et al., 2013) that display a high sequence homology with membrane bound GCs in these domains (PDB codes: 3HLS and 3UVJ). Assembly and topography of GC domains, in particular of the DD and CCD is arbitrarily chosen. GCAP1 and GCAP2 activate the target GC at low cytoplasmic $\mathrm{Ca}^{2+}$-concentration bringing the cell back to the dark state. The exact regions of interaction and/or regulation by GCAPs are a matter of debate (see main text). Interaction with other proteins was shown by biochemical procedures, but physiological meaning is lacking so far. Structures of GCAP1 and GCAP2 are based on the published $x$-ray and NMR-structure, respectively (GCAP1: 2R2I, Stephen et al., 2007; GCAP2: 1JBA, Ames et al., 1999).

Detailed biochemical characterization of GCAP properties in combination with the analysis of transgenic mice showed that GCAPs differ in their $\mathrm{Ca}^{2+}$-sensitivity, $\mathrm{Ca}^{2+}$-binding properties and target regulatory features (Mendez et al., 2001; Hwang et al., 2003; Peshenko et al., 2011b). These results led to a concept of GCAPs activating the target in a sequential order depending on the actual cytoplasmic $\mathrm{Ca}^{2+}$-concentration in the rod or cone cell (Hwang et al., 2003; Koch, 2006; Makino et al., 2012; Koch and Dell'Orco, 2013). For example, mammalian GCAP1 is active at higher $\mathrm{Ca}^{2+}$-concentration than GCAP2. This means in physiological terms that after a single flash of light, when $\mathrm{Ca}^{2+}$-decreases in the cell, GCAP1 will first loose its bound $\mathrm{Ca}^{2+}$ and turn into an activator before GCAP2 would step into this $\mathrm{Ca}^{2+}$-feedback loop. Electrophysiological recordings and computational modeling of photoresponses have further supported a $\mathrm{Ca}^{2+}$-relay or recruitment model of GCAP action (Koch and Dell'Orco, 2013; Wen et al., 2014). Based on differences in spatialtemporal expression profiles (Rätscho et al., 2009), $\mathrm{Ca}^{2+}$. sensitive target regulation and $\mathrm{Ca}^{2+}$-binding of multiple GCAP isoforms (Scholten and Koch, 2011; Sulmann et al., 2015) a similar concept has been proposed for the operation of these $\mathrm{Ca}^{2+}$-sensors in zebrafish rod and cone cells (Koch, 2013). 
GCAPs share a high degree of amino acid sequence identity and structural homology in cases where the three-dimensional folding had been determined (Ames et al., 1999; Stephen et al., 2007). However, the protein dynamics of $\mathrm{Ca}^{2+}$-triggered conformational changes show significant differences between mammalian GCAP1 and GCAP2 on a nanosecond time scale. Fluorescence lifetime and anisotropy measurements of GCAP1 and GCAP2 that were site specifically labeled with the dye Alexa647 revealed different movements of secondary structural elements (Kollmann et al., 2012; Robin et al., 2015). In the case of GCAP1 these findings were further supported by molecular dynamics simulation showing that GCAP1 undergoes a twisted accordion-like movement upon changing $\mathrm{Ca}^{2+}$-concentration (Robin et al., 2015). GCAP2 in contrast responds to a change in $\mathrm{Ca}^{2+}$ by an up-and-down or piston-like movement of an $\alpha$-helix between amino acid positions 111 and 131 (Kollmann et al., 2012; Figure 5). A main conclusion from these studies was that two structurally similar proteins can differ significantly in their conformational structural dynamics thereby providing structural framework for their different regulatory responses.

Mutations in the retinal degeneration 3 protein (RD3) correlate with type 12 of Leber congenital amaurosis causing a severe form of blindness at early age (Friedman et al., 2006; Preising et al., 2012). The RD3 protein binds to photoreceptor specific GCs 1 and 2 (ROS-GC1 and ROS-GC2) and both proteins are not detectable in rods and cones of RD3 deficient mice (Azadi et al., 2010). Studies using RD3 and ROS-GC1 transfected COS-7 cells and by delivering the RD3 gene into an RD3 deficient mice strain by subretinal injection (Molday et al., 2013) revealed that RD3 is necessary for the correct translocation and cellular localization of ROS-GC1 (Azadi et al., 2010; Zulliger et al., 2015). RD3 does not only bind to GC1, but can act as an allosteric modulator inhibiting ROS-GC1 activity (Peshenko et al., 2011b; Figure 4).

The multiple binding and regulatory processes of the GC signaling unit leave several issues unresolved. For example, published work concerning the binding sites in the GC are inconclusive, since direct interaction sites for GCAP1 and GCAP2 have been mapped to different intracellular regions in ROS-GC1 (Figure 4) including the juxtamembrane domain (JMD; Duda et al., 1999a; Lange et al., 1999), the kinase homology domain (KHD; Krylov and Hurley, 2001) and the cyclase catalytic domain (CCD; Sokal et al., 1999b; Duda et al., 2005). Findings were based on different experimental approaches like peptide competition using peptide libraries, site-directed mutagenesis, and crosslinking in combination with mass spectrometry and might reflect different protein complexes due to the transitory nature of the GCAP-GC interaction mode (see above). However, a more recent paper claims that GCAP1 and GCAP2 bind to overlapping binding sites in a mutually exclusive manner (Peshenko et al., 2015a). A further major unresolved issue in understanding the GC signaling complex is how conformational changes in allosteric regulators (GCAPs) are transmitted to the catalytic site to increase the GC enzymatic turnover rate at least by a factor of 10. A critical role in sensing these conformational changes seems to play the dimerization domain (DD) of the cyclase. This domain forms a coiled-coil structure that is disrupted or in some cases even tightened in a number of retinal disease related mutations causing defects in the $\mathrm{Ca}^{2+}$-dependent control of GC activity (Duda et al., 1999b, 2000; Ramamurthy et al., 2001; Zägel et al., 2013). Very recently experimental evidence was presented showing that the DDis part of the GCAP binding interface (Peshenko et al., 2015b).

The differential regulation of GCs is not limited to GCAPs, but includes other $\mathrm{Ca}^{2+}$-sensor proteins as well. Neurocalcin $\delta$ (Kumar et al., 1999; Venkataraman et al., 2008) and S100B (Duda et al., 2002) target to binding sites in ROS-GC1 that are localized in the CCD or the C-terminal extension (CTE). Both $\mathrm{Ca}^{2+}$ sensors regulate the activity of ROS-GC1 in a $\mathrm{Ca}^{2+}$-dependent manner, but opposite to the GCAP mode indicating that these operation modes do not participate in outer segment physiology (Venkataraman et al., 2003), but are rather localized in other photoreceptor cell compartments, for example in modulating the signal transmission to cone ON-bipolar cells (Wen et al., 2012).

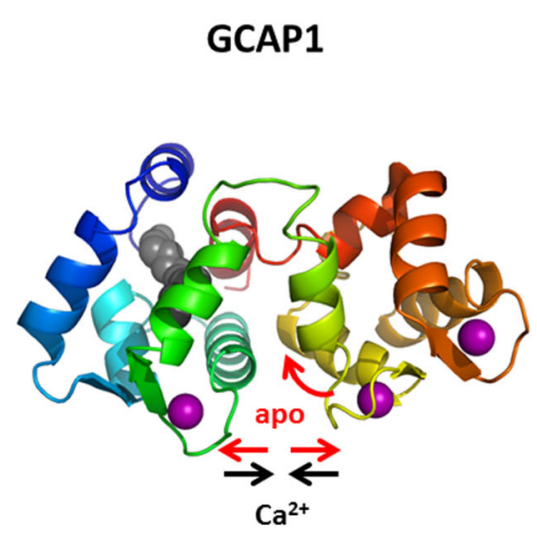

\section{GCAP2}

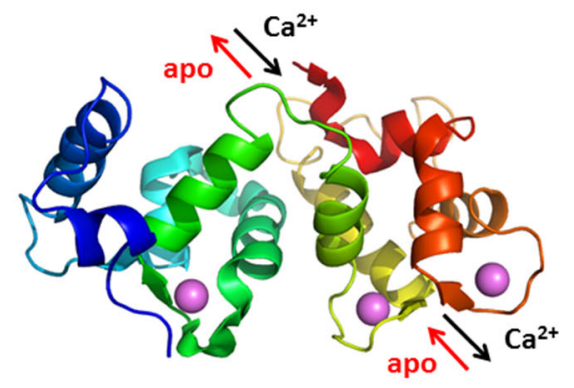

FIGURE 5 | Protein dynamics of GCAP1 and GCAP2. Binding and dissociation of $\mathrm{Ca}^{2+}$ (violet spheres) triggers different conformational changes and movements of secondary structural elements, a twisted accordion-like movement in GCAP1 and a piston-like movement of one $\alpha$-helix (yellow) in GCAP2. 


\section{PROTEIN ASSEMBLY PROVIDING A STRUCTURAL LINK BETWEEN PLASMA AND DISC MEMBRANE}

CNG channels are heterotetrameric proteins consisting, in rod and cone cells, of three $\alpha$-subunits and one $\beta$-subunit (Weitz et al., 2002; Zheng et al., 2002). The subunits however are specific for each cell type and are designated CNGA1 and CNGB1 for the rod channel and CNGA3 and CNGB3 for the cone channel. The $\beta$-subunit CNGB1 of the rod channel has a unique structure, since it has an extended $\mathrm{NH}_{2}$-terminal part containing four proline-rich repeats and a glutamic acid rich part, which is therefore named glutamic acid rich protein (GARP) part (Sugimoto et al., 1991; Körschen et al., 1995; Colville and Molday, 1996). GARP is also expressed as two soluble protein variants (GARP1 and GARP2). Interaction of the GARP part of CNGB1 with disc membrane proteins at the rim region of the discs has been shown for the retina specific $\mathrm{ABC}$-binding cassette (ABCR) transporter (Körschen et al., 1999) and for the peripherin2/ROM-1 complex (Poetsch et al., 2001; Becirovic et al., 2014). The CNG channel interacts further in the plasma membrane with the $\mathrm{Na}^{+} / \mathrm{Ca}^{2+}, \mathrm{K}^{+}$-exchanger (Schwarzer et al., 2000; Kang et al., 2003). The oligomeric protein assembly around the CNG channel constitutes a highly organized microdomain in the rod cell consistent with a role of GARPs in maintaining structural integrity (Körschen et al., 1999; Poetsch et al., 2001; Zhang et al., 2009). The physiological role of different GARP variants however has not been fully explored and is still under discussion. For example, the soluble GARP variant GARP2 binds PDE6 with high affinity thereby inhibiting its basal activity (Pentia et al., 2006); it further controls the open probability of the CNG channel by acting as a gate keeper (Michalakis et al., 2011). These two mechanisms would lead to a reduction in dark noise (Pentia et al., 2006; Michalakis et al., 2011). Overexpressing GARP2 has an effect on the phototransduction gain as derived from fitting the rising phase of the electroretinogram a-wave response (Sarfare et al., 2014). The same study showed also a slower

\section{REFERENCES}

Allerston, C. K., von Delft, F., and Gileadi, O. (2013). Crystal structures of the catalytic domain of human soluble guanylate cyclase. PLoS One 8:e57644. doi: 10.3410/f.718029832.793480138

Ames, J. B., Dizhoor, A. M., Ikura, M., Palczewski, K., and Stryer, L. (1999). Threedimensional structure of guanylyl cyclase activating protein-2, a calciumsensitive modulator of photoreceptor guanylyl cyclases. J. Biol. Chem. 274, 19329-19337. doi: 10.1074/jbc.274.27.19329

Ames, J. B., Ishima, R., Tanaka, T., Gordon, J. I., Stryer, L., and Ikura, M. (1997). Molecular mechanics of calcium-myristoyl switches. Nature 389, 198-202.

Ames, J. B., Levay, K., Wingard, J. N., Lusin, J. D., and Slepak, V. Z. (2006). Structural basis for calcium-induced inhibition of rhodopsin kinase by recoverin. J. Biol. Chem. 281, 37237-37245. doi: 10.1074/jbc.m606913200

Arshavsky, V. Y. and Burns, M. E. (2012). Photoreceptor signaling: supporting vision across a wide range of light intensities. J. Biol. Chem. 287, 1620-1626. doi: 10.1074/jbc.r111.305243

Asteriti, S., Dal Cortivo, G., Pontelli, V., Cangiano, L., Buffelli, M., and Dell'Orco, D. (2015). Effective delivery of recombinant proteins to rod photoreceptors via lipid nanovesicles. Biochem. Biophys. Res. Commun. 461, 665-670. doi: 10. 1016/j.bbrc.2015.04.088 shutoff of the photoresponse. Reconciliation of physiological recordings with functional studies of isolated GARP proteins is hampered by their "intrinsically unfolded nature", which is known from biochemical and structural analysis of GARP forms (Batra-Safferling et al., 2006). This property however, would make them suitable as flexible tethering proteins linking the $\mathrm{CNG}$ channel/exchanger complex with the rim region of the disc membrane.

\section{CONCLUDING REMARKS}

Signaling proteins in photoreceptor cells form building blocks and signaling modules involving the disc membranes as platforms. These units might preferably exist of transitory protein complexes that are determined by the affinities of their binding partners and their lateral and longitudinal diffusion. This flexible regulatory network of proteins therefore creates the heterogeneous distribution of signaling units in the outer segment under conditions of a crowded intracellular environment. It will be a future challenge to investigate how the exchange, flow and mutual interaction of key factors in signaling units determines the preciseness of visual phototransduction and adaptation.

\section{AUTHOR CONTRIBUTIONS}

KWK developed the concept of the manuscript, wrote the first draft and approved the final version. DDO added to all parts of the manuscript and approved the final version.

\section{ACKNOWLEDGMENTS}

The theoretical and experimental work performed in the laboratories of the authors has been funded by different grants from the Deutsche Forschungsgemeinschaft (DFG) to KWK and by the Italian Ministry for Education and Research via departmental grants to DDO.

Azadi, S., Molday, L. L., and Molday, R. S. (2010). RD3, the protein associated with Leber congenital amaurosis type 12, is required for guanylate cyclase trafficking in photoreceptor cells. Proc Natl. Acad. Sci. U S A 107, 21158-21163. doi: 10. 3410/f.6564958.6698056

Baehr, W., Karan, S., Maeda, T., Luo, D. G., Li, S., Bronson, J. D., et al. (2007). The function of guanylate cyclase 1 and guanylate cyclase 2 in rod and cone photoreceptors. J. Biol. Chem. 282, 8837-8847. doi: 10.1074/jbc.m6103 69200

Balasubramanian, N., and Slepak, V. Z. (2003). Light-mediated activation of Rac-1 in photoreceptor outer segments. Curr. Biol. 13, 1306-1310. doi: 10. 1016/s0960-9822(03)00511-6

Batra-Safferling, R., Abarca-Heidemann, K., Körschen, H. G., Tziatzios, C., Stoldt, M., Budyak, I., et al. (2006). Glutamic acid-rich proteins of rod photoreceptors are natively unfolded. J. Biol. Chem. 281, 1449-1460. doi: 10. 1074/jbc.m505012200

Baylor, D. A., and Lamb, T. D. (1982). Local effects of bleaching in retinal rods of the toad. J. Physiol 328, 49-71. doi: 10.1113/jphysiol.1982.sp014252

Becirovic, E., Nguyen, O. N., Paparizos, C., Butz, E. S., Stern-Schneider, G., Wolfrum, U., et al. (2014). Peripherin-2 couples rhodopsin to the CNG channel in outer segments of rod photoreceptors. Hum. Mol. Genet. 23, 5989-5997. doi: $10.1093 / \mathrm{hmg} / \mathrm{ddu} 323$ 
Berta, A. I., Boesze-Battaglia, K., Magyar, A., Szél, A., and Kiss, A. L. (2011). Localization of caveolin-1 and c-src in mature and differentiating photoreceptors: raft proteins co-distribute with rhodopsin during development. J. Mol. Histol. 42, 523-533. doi: 10.1007/s10735-0119360-4

Bisegna, P., Caruso, G., Andreucci, D., Shen, L., Gurevich, V. V., Hamm, H. E., et al. (2008). Diffusion of the second messengers in the cytoplasm acts as a variability suppressor of the single photon response in vertebrate phototransduction. Biophys J. 94, 3363-3383. doi: 10.1529/biophysj.107. 114058

Boesze-Battaglia, K., and Albert, A. D. (1990). Cholesterol modulation of photoreceptor function in bovine retinal rod outer segments. J. Biol. Chem. 265, 20727-20730

Boesze-Battaglia, K., Fliesler, S. J., and Albert, A. D. (1990). Relationship of cholesterol content to spatial distribution and age of disc membranes in retinal rod outer segments. J. Biol. Chem. 265, 18867-18870.

Boesze-Battaglia, K., Hennessey, T., and Albert, A. D. (1989). Cholesterol heterogeneity in bovine rod outer segment disk membranes. J. Biol. Chem. 264, 8151-8155.

Burgoyne, R. D., and Haynes, L. P. (2015). Sense and specificity in neuronal calcium signalling. Biochim. Biophys. Acta 1853, 1921-1932. doi: 10.1016/j. bbamcr.2014.10.029

Burns, M. E. (2010). Deactivation mechanisms of rod phototransduction. Invest. Ophthalmol. Vis. Sci. 51, 1282-1288. doi: 10.1167/iovs.09-4366

Bush, R. A., and Makino, C. (2006). "Recoverin shapes the photoresponse of retinal rods," in Neuronal Calcium Sensor Proteins eds P. P. Philippov and K.-W. Koch (Hauppauge, NY: Nova Publishers), 153-180.

Buzhynskyy, N., Salesse, C., and Scheuring, S. (2011). Rhodopsin is spatially heterogeneously distributed in rod outer segment disk membranes. J. Mol. Recognit. 24, 483-489. doi: 10.1002/jmr.1086

Calvert, P. D., Strissel, K. J., Schiesser, W. E., and Pugh, E. N. and Arshavsky, V. Y. (2006). Light-driven translocation of signaling proteins in vertebrate photoreceptors. Trends Cell Biol. 16, 560-568. doi: 10.1016/j.tcb.2006.09.001

Cangiano, L., and Dell'Orco, D. (2013). Detecting single photons: a supramolecular matter? FEBS Lett. 587, 1-4. doi: 10.1016/j.febslet.2012. 11.015

Chabre, M., Cone, R., and Saibil, H. (2003). Biophysics: is rhodopsin dimeric in native retinal rods? Nature 426, 30-31. doi: 10.1038/426030b

Chabre, M., and le Maire, M. (2005). Monomeric G-protein-coupled receptor as a functional unit. Biochemistry 44, 9395-9403. doi: 10.1021/bi050720o

Chen, C. K., Inglese, J., Lefkowitz, R. J., and Hurley, J. B. (1995). $\mathrm{Ca}^{2+}$. dependent interaction of recoverin with rhodopsin kinase. J. Biol. Chem. 270, 18060-18066. doi: $10.1074 / j b c .270 .30 .18060$

Chen, C. K., Woodruff, M. L., and Fain, G. L. (2015). Rhodopsin kinase and recoverin modulate phosphodiesterase during mouse photoreceptor light adaptation. J. Gen. Physiol. 145, 213-224. doi: 10.1085/jgp.201411273

Chen, C. K., Woodruff, M. L., Chen, F. S., Chen, Y., Ciluffo, M. C., Tranchina, D., et al. (2012). Modulation of mouse rod response decay by rhodopsin kinase and recoverin. J. Neurosci. 32, 15998-16006. doi: 10.1523/jneurosci.1639-12. 2012

Chen, C. K., Woodruff, M. L., Chen, F. S., Chen, D., and Fain, G. L. (2010). Background light produces a recoverin-dependent modulation of activatedrhodopsin lifetime in mouse rods. J. Neurosci. 30, 1213-1220. doi: 10. 1523/jneurosci.4353-09.2010

Colville, C. A., and Molday, R. S. (1996). Primary structure and expression of the human beta-subunit and related proteins of the rod photoreceptor cGMP-gated channel. J. Biol. Chem. 271, 32968-32974. doi: 10.1074/jbc.271.51.32968

Cone, R. A. (1972). Rotational diffusion of rhodopsin in the visual receptor membrane. Nat. New Biol. 236, 39-43. doi: 10.1038/newbio236039a0

Dell'Orco, D. (2013). A physiological role for the supramolecular organization of rhodopsin and transducin in rod photoreceptors. FEBS Lett. 587, 2060-2066. doi: 10.1016/j.febslet.2013.05.017

Dell'Orco, D. (2015). Rhodopsin transient complexes investigated by systems biology approaches. Methods Mol. Biol. 1271, 251-263. doi: 10.1007/978-14939-2330-4_17

Dell'Orco, D., and Koch, K. W. (2011). A dynamic scaffolding mechanism for rhodopsin and transducin interaction in vertebrate vision. Biochem. J. 440, 263-271. doi: 10.1042/bj20110871
Dell'Orco, D., and Koch, K. W. (2015). Transient complexes between dark rhodopsin and transducin: circumstantial evidence or physiological necessity? Biophys. J. 108, 775-777. doi: 10.1016/j.bpj.2014.12.031

Dell'Orco, D., and Schmidt, H. (2008). Mesoscopic Monte Carlo simulations of stochastic encounters between photoactivated rhodopsin and transducin in disc membranes. J. Phys. Chem. B. 112, 4419-4426. doi: 10.1021/jp $709963 \mathrm{f}$

Dell'Orco, D., Schmidt, H., Mariani, S. and Fanelli, F. (2009). Network-level analysis of light adaptation in rod cells under normal and altered conditions. Mol. Biosyst. 5, 1232-1246. doi: 10.1039/b908123b

Dell'Orco, D., Seeber, M., and Fanelli, F. (2007). Monomeric dark rhodopsin holds the molecular determinants for transducin recognition: insights from computational analysis. FEBS Lett. 581, 944-948. doi: 10.1016/j.febslet.2007. 01.074

Dizhoor, A. M., Ericsson, L. H., Johnson, R. S., Kumar, S., Olshevskaya, E., Zozulya, S., et al. (1992). The NH2 terminus of retinal recoverin is acylated by a small family of fatty acids. J. Biol. Chem. 267, 16033-16036.

Dizhoor, A. M., Lowe, D. G., Olshevskaya, E. V., Laura, R. P., and Hurley, J. B. (1994). The human photoreceptor membrane guanylyl cyclase, RetGC, is present in outer segments and is regulated by calcium and a soluble activator. Neuron 12, 1345-1352. doi: 10.1016/0896-6273(94) 90449-9

Dizhoor, A. M., Olshevskaya, E. V., and Peshenko, I. V. (2010). $\mathrm{Mg}^{2+} / \mathrm{Ca}^{2+}$ cation binding cycle of guanylyl cyclase activating proteins (GCAPs): role in regulation of photoreceptor guanylyl cyclase. Mol. Cell. Biochem. 334, 117-124. doi: 10.1007/s11010-009-0328-6

Dizhoor, A. M., Olshevskaya, E. V., Henzel, W. J., Wong, S. C., Stults, J. I., Ankoudinova, I., et al. (1995). Cloning, sequencing and expression of a $24-\mathrm{kDa}$ $\mathrm{Ca}^{2+}$-binding protein activating photoreceptor guanylyl cyclase. J. Biol. Chem. 270, 25200-25206. doi: 10.1074/jbc.270.42.25200

Duda, T., Fik-Rymarkiewicz, E., Venkataraman, V., Krishnan, R., Koch, K. W., and Sharma, R. K. (2005). The calcium-sensor guanylate cyclase activating protein type 2-specific site in rod outer segment membrane guanylate cyclase type 1 . Biochemistry 44, 7336-7345. doi: 10.1021/bi050068x

Duda, T., Koch, K. W., Venkataraman, V., Lange, C., Beyermann, M., and Sharma, R. K. (2002). $\mathrm{Ca}^{2+}$-sensor $\mathrm{S} 100 \beta$ modulated sites of membrane guanylate cyclase in the photoreceptor-bipolar synapse. EMBO J. 21, 2547-2556. doi: 10. 1093/emboj/21.11.2547

Duda, T., Krishnan, A., Venkataraman, V., Lange, C., Koch, K. W., and Sharma, R. K. (1999a). Mutations in the rod outer segment membrane guanylate cyclase (ROS-GC1) in a cone-rod dystrophy cause defects in calcium signaling. Biochemistry 38, 13912-13919. doi: 10.1021/bi9915972

Duda, T., Venkataraman, V., Goraczniak, R., Lange, C., Koch, K.-W., and Sharma, R. K. (1999b). Functional consequences of a rod outer segment membrane guanylate cyclase (ROS-GC1) gene mutation linked with leber's congenital amaurosis. Biochemistry 38, 509-515. doi: 10.1021/bi9824137

Duda, T., Venkataraman, V., Jankowska, A., Lange, C., Koch, K. W., and Sharma, R. K. (2000). Impairmment of the rod outer segment membrane guanylate cyclase dimerization in a cone-rod dystrophy results in defective calcium signaling. Biochemistry 39, 12522-12533. doi: 10.1021/bi00 $1514 \mathrm{~d}$

Elliott, M. H., Fliesler, S. J., and Ghalayini, A. J. (2003). Cholesteroldependent association of caveolin-1 with the transducin alpha subunit in bovine photoreceptor rod outer segments: disruption by cyclodextrin and guanosine 5'-O-(3-thiotriphosphate). Biochemistry 42, 7892-7903. doi: 10. $1021 / \mathrm{bi027162n}$

Elliott, M. H., Nash, Z. A., Takemori, N., Fliesler, S. J., McClellan, M. E., and Naash, M. I. (2008). Differential distribution of proteins and lipids in detergent-resistant and detergent-soluble domains in rod outer segment plasma membranes and disks. J. Neurochem. 104, 336-352. doi: 10.1111/j.14714159.2007.04971.x

Ernst, O. P., Gramse, V., Kolbe, M., Hofmann, K. P., and Heck, M. (2007). Monomeric $\mathrm{G}$ protein-coupled receptor rhodopsin in solution activates its $\mathrm{G}$ protein transducin at the diffusion limit. Proc. Natl. Acad. Sci. U S A 104, 10859-10864.

Fanelli, F., and Dell'Orco, D. (2005). Rhodopsin activation follows precoupling with transducin: inferences from computational analysis. Biochemistry 44, 14695-14700. doi: 10.1021/bi051537y 
Fleischmann, D., and Denisevich, M. (1979). Guanylate cyclase of isolated bovine retinal rod axonemes. Biochemistry 18, 5060-5066. doi: 10.1021/bi005 $90 \mathrm{a} 006$

Fotiadis, D., Liang, Y., Filipek, S., Saperstein, D. A., Engel, A., and Palczewski, K. (2003a). Atomic-force microscopy: Rhodopsin dimers in native disc membranes. Nature 421, 127-128. doi: 10.1038/421127a

Fotiadis, D., Liang, Y., Filipek, S., Saperstein, D. A., Engel, A., and Palczewski, K. (2003b). Reply to Chabre et al., biophysics: is rhodopsin dimeric in native retinal rods? Nature 426, 31. doi: 10.1038/426030b

Fotiadis, D., Liang, Y., Filipek, S., Saperstein, D. A., Engel, A., and Palczewski, K. (2004). The $G$ protein-coupled receptor rhodopsin in the native membrane. FEBS Lett. 564, 281-288.

Friedman, J. S., Chang, B., Kannabiran, C., Chakarova, C., Singh, H. P., Jalali, S., et al. (2006). Premature truncation of a novel protein, RD3, exhibiting subnuclear localization is associated with retinal degeneration. Am. J. Hum. Genet. 79, 1059-1070. doi: 10.1086/510021

Fries, R., Scholten, A., Säftel, W., and Koch, K. W. (2012). Operation profile of zebrafish guanylate cyclase-activating protein 3. J. Neurochem. 121, 54-65. doi: 10.1111/j.1471-4159.2011.07643.x

Frins, S., Bönigk, W., Müller, F., Kellner, R., and Koch, K. W. (1996). Functional characterization of a guanylyl cyclase-activating protein from vertebrate rods. J. Biol. Chem. 271, 8022-8027. doi: 10.1074/jbc.271.14.8022

Goraczniak, R. M., Duda, T., Sitaramayya, A., and Sharma, R. K. (1994). Structural and functional characterization of the rod outer segment membrane guanylate cyclase. Biochem J. 302, 455-461. doi: 10.1042/bj3020455

Gorodovikova, E. N., Senin, I. I., and Philippov, P. P. (1994). Calcium-sensitive control of rhodopsin phosphorylation in the reconstituted system consisting of photoreceptor membranes, rhodopsin kinase and recoverin. FEBS Lett 353, 171-172. doi: 10.1016/0014-5793(94)01030-7

Govardovskii, V. I., Korenyak, D. A., Shukolyukov, S. A., and Zueva, L. V. (2009). Lateral diffusion of rhodopsin in photoreceptor membrane: a reappraisal. Mol. Vis. 15, 1717-1729.

Granzin, J., Cousin, A., Weirauch, M., Schlesinger, R., Büldt, G., and BatraSafferling, R. (2012). Crystal structure of p44, a constitutively active splice variant of visual arrestin. J. Mol. Biol. 416, 611-618. doi: 10.1016/j.jmb.2012. 01.028

Gray-Keller, M., Denk, W., Shraiman, B., and Detwiler, P. B. (1999). Longitudinal spread of second messenger signals in isolated rod outer segments of lizards. J. Physiol. 519, 679-692. doi: 10.1111/j.1469-7793.1999.0679n.x

Grigoriev, I. I., Senin, I. I., Tikhomirova, N. K., Komolov, K. E., Permyakov, S. E., Zernii, E. Y., et al. (2012). Synergetic effect of recoverin and calmodulin on regulation of rhodopsin kinase. Front. Mol. Neurosci. 5:28. doi: 10.3389/fnmol. 2012.00028

Gunkel, M., Schöneberg, J., Alkhaldi, W., Irsen, S., Noé, F., Kaupp, U. B., et al. (2015). Higher-order architecture of rhodopsin in intact photoreceptors and its implication for phototransduction kinetics. Structure 23, 628-638. doi: 10. 1016/j.str.2015.01.015

Hallett, M. A., Delaat, J. L., Arikawa, K., Schlamp, C. L., Kong, F., and Williams, D. S. (1996). Distribution of guanylate cyclase within photoreceptor outer segments. J. Cell Sci. 109, 1803-1812.

Hamer, R. D., Nicholas, S. C., Tranchina, D., Lamb, T. D., and Jarvinen, J. L. (2005). Toward a unified model of vertebrate rod phototransduction. Vis. Neurosci. 22, 417-436. doi: 10.1017/s09525238052 24045

Hayashi, F., and Yamazaki, A. (1991). Polymorphism in purified guanylate cyclase from vertebrate rod photoreceptors. Proc. Natl. Acad. Sci. U S A 88, 4746-4750. doi: 10.1073/pnas.88.11.4746

Higgins, M. K., Oprian, D. D., and Schertler, G. F. X. (2006). Recoverin binds exclusively to an amphipathic peptide at the $\mathrm{N}$ terminus of rhodopsin kinase, inhibiting rhodopsin phosphorylation without affecting catalytic activity of the kinase. J. Biol. Chem. 281, 19426-19432. doi: 10.1074/jbc.m602203200

Huang, C. C., Orban, T., Jastrzebska, B., Palczewski, K., and Tesmer, J. J. (2011). Activation of G protein-coupled receptor kinase 1 involves interactions between its N-terminal region and its kinase domain. Biochemistry 50, 1940-1949. doi: 10.1021/bi101606e

Huang, C. C., Yoshino-Koh, K., and Tesmer, J. J. (2009). A surface of the kinase domain critical for the allosteric activation of $G$ protein-coupled receptor kinases. J. Biol. Chem. 284, 17206-17215. doi: 10.1074/jbc.m809544200
Hwang, J. Y., and Koch, K. W. (2002). The myristoylation of the neuronal $\mathrm{Ca}^{2+}$. sensors guanylate cyclase-activating protein 1 and 2. Biochim. Biophys. Acta 1600, 111-117. doi: 10.1016/s1570-9639(02)00451-x

Hwang, J. Y., Lange, C., Helten, A., Höppner-Heitmann, D., Duda, T., Sharma, R. K., et al. (2003). Regulatory modes of rod outer segment membrane guanylate cyclase differ in catalytic efficiency and $\mathrm{Ca}^{2+}$-sensitivity. Eur. J. Biochem. 270, 3814-3821. doi: 10.1046/j.1432-1033.2003. 03770.x

Hwang, J. Y., Schlesinger, R., and Koch, K. W. (2001). Calcium-dependent cysteine reactivities in the neuronal calcium sensor guanylate cyclase-activating protein 1. FEBS Lett. 508, 355-359. doi: 10.1016/s0014-5793(01)03094-0

Imanishi, Y., Yang, L., Sokal, I., Filipek, S., Palczewski, K., and Baehr, W. (2004). Diversity of guanylate cyclase-activating proteins (GCAPS) in teleost fish: characterization of three novel GCAPs (GCAP4, GCAP5, GCAP7) from zebrafish (Danio rerio) and prediction of eight GCAPs (GCAP1-8) in pufferfish (Fugu rubripes). J. Mol. Evol. 59, 204-217. doi: 10.1007/s00239-0042614-y

Invergo, B. M., Dell'Orco, D., Montanucci, L., Koch, K. W., and Bertrandpetit, J. (2014). A comprehensive model of the phototransduction cascade in mouse rod cells. Mol. Biosyst. 10, 1481-1489. doi: 10.1039/c3mb70584f

Invergo, B. M., Montanucci, L., Koch, K. W., Bertranpetit, J., and Dell'Orco, D. (2013). Exploring the rate-limiting steps in visual phototransduction recovery by bottom-up kinetic modeling. Cell Commun. Signal 11: 36. doi: 10.1186/1478811x-11-36

Jastrzebska, B., Chen, Y., Orban, T., Jin, H., Hofmann, L., and Palczewski, K. (2015). Disruption of rhodopsin dimerization with synthetic peptides targeting an interaction interface. J. Biol. Chem. 290, 25728-25744. doi: 10.1074/jbc. m115.662684

Jastrzebska, B., Maeda, T., Zhu, L., Fotiadis, D., Filipek, S., Engel, A., et al. (2004). Functional characterization of rhodopsin monomers and dimers in detergents. J. Biol. Chem. 279, 54663-54675. doi: 10.1074/jbc.m4086 91200

Kang, K., Bauer, P. J., Kinjo, T. G., Szerencsei, R. T., Bönigk, W., Winkfein, R. J., et al. (2003). Assembly of retinal rod or cone $\mathrm{Na}^{+} / \mathrm{Ca}^{2+}-\mathrm{K}^{+}$exchanger oligomers with cGMP-gated channel subunits as probed with heterologously expressed cDNAs. Biochemistry 42, 4593-4600. doi: 10.1021/bi027276z

Karan, S., Frederick, J. M. and Baehr, W. (2010). Novel functions of photoreceptor guanylate cyclases revealed by targeted deletion. Mol. Cell. Biochem. 334, 141-155. doi: 10.1007/s11010-009-0322-Z

Kaupp, U. B., and Koch, K. W. (1992). Role of cGMP and $\mathrm{Ca}^{2+}$ in vertebrate photoreceptor excitation and adaptation. Ann. Rev. Physiol. 54, 153-175. doi: 10.1146/annurev.physiol.54.1.153

Kaupp, U. B., Seifert, R. (2002). Cyclic nucleotide-gated ion channels. Physiol. Rev. 82, 769-824. doi: 10.1152/physrev.00008.2002

Kawamura, S. (1993). Rhodopsin phosphorylation as a mechanism of cyclic GMP phosphodiesterase regulation by S-modulin. Nature 362, 855-857. doi: 10 . $1038 / 362855 \mathrm{a} 0$

Kiel, C., Vogt, A., Campagna, A., Chatr-aryamontri, A., Swiatek-de Lange, M., Beer, M., et al. (2011). Structural and fuctional protein network analyses predict novel signalling functions for rhodopsin. Mol. Syst. Biol. 7: 551. doi: 10. 1038/msb.2011.83

Kim, Y. J., Hofmann, K. P., Ernst, O. P., Scheerer, P., Choe, H. W., and Sommer, M. E. (2013). Crystal structure of pre-activated arrestin p44. Nature 497, 142-146. doi: 10.1038/nature12133

Klenchin, V. A., Calvert, P. D., and Bownds, M. D. (1995). Inhibition of rhodopsin kinase by recoverin. Further evidence for a negative feedback system in phototransduction. J. Biol. Chem. 270, 16147-16152. doi: 10.1074/jbc.270.27. 16147

Koch, K. W. (1991). Purification and identification of photoreceptor guanylate cyclase. J. Biol. Chem. 266, 8634-8637.

Koch, K. W. (1994). Calcium as modulator of phototransduction in vertebrate photoreceptor cells. Rev. Physiol. Biochem. Pharmacol. 125, 149-192. doi: 10. 1007/bfb0030910

Koch, K. W. (2006). GCAPs, the classical neuronal calcium sensors in the retina $\mathrm{a} \mathrm{Ca}^{2+}$-relay model of guanylate cyclase activation. Calcium Binding Proteins 1, 3-6.

Koch, K. W. (2013). The guanylate cyclase signaling system in zebrafish photoreceptors. FEBS Lett. 587, 2055-2059. doi: 10.1016/j.febslet.2013.04.023 
Koch, K. W., and Dell'Orco, D. (2013). A Calcium-Relay Mechanism in Vertebrate Phototransduction. ACS Chem. Neurosci. 4, 909-917. doi: 10.1021/cn4 $00027 \mathrm{z}$

Koch, K. W., and Stryer, L. (1988). Highly cooperative feedback control of retinal rod guanylate cyclase by calcium ions. Nature 334, 64-66. doi: 10 . 1038/334064a0

Koch, K.-W., Duda, T., and Sharma, R. K. (2010). $\mathrm{Ca}^{2+}$-modulated vision-linked ROS-GC guanylate cyclase transduction machinery. Mol. Cell. Biochem. 334, 105-115. doi: 10.1007/s11010-009-0330-z

Kollmann, H., Becker, S. F., Shirdel, J., Scholten, A., Ostendorp, A., Lienau, C., et al. (2012). Probing the $\mathrm{Ca}^{2+}$ switch of the neuronal $\mathrm{Ca}^{2+}$ sensor GCAP2 by time-resolved fluorescence spectroscopy. ACS Chem. Biol. 7, 1006-1014. doi: $10.1021 / \mathrm{cb} 3000748$

Komolov, K. E., Senin, I. I., Kovaleva, N. A., Christoph, M. P., Churumova, V. A., Grogoriev, I. I., et al. (2009). Mechanism of rhodopsin kinase regulation by recoverin. J. Neurochem. 110, 72-79. doi: 10.1111/j.1471-4159.2009.06118.x

Korenbrot, J. I. (2012). Speed, sensitivity and stability of the light response in rod and cone photoreceptors: facts and models. Prog. Ret. Eye Res. 31, 442-466. doi: 10.1016/j.preteyeres.2012.05.002

Körschen, H. G., Beyermann, M., Müller, F., Heck, M., Vantler, M., Koch, K. W., et al. (1999). Interaction of glutamic acid-rich proteins with components of the cGMP-signaling pathway in rod photoreceptors. Nature 400, 761-766. doi: 10 . $1038 / 23468$

Körschen, H. G., Illing, M., Seifert, R., Sesti, F., Williams, A., Gotzes, S., et al. (1995). A $240 \mathrm{kDa}$ protein represents the complete beta subunit of the cyclic nucleotide-gated channel from rod photoreceptor. Neuron 15, 627-636. doi: 10. 1016/0896-6273(95)90151-5

Köster, M., Dell'Orco, D., and Koch, K. W. (2014). The interaction network of rhodopsin involving the heterotrimeric G-protein transducin and the monomeric GTPase Rac1 is determined by distinct binding processes. FEBS J. 281, 5175-5185. doi: 10.1111/febs.13064

Krispel, C. M., Chen, D., Melling, N., Chen, Y. J., Martemyanov, K. A., Quillinan, N., et al. (2006). RGS expression rate-limits recovery of rod photoresponses. Neuron. 51, 409-416. doi: 10.3410/f.1040096.489013

Krylov, D. M., and Hurley, J. B. (2001). Identification of proximate regions in a complex of retinal guanylyl cyclase 1 and guanylyl cyclase-activating protein-1 by a novel mass spectrometry-based method. J. Biol. Chem. 276, 30648-30654. doi: 10.1074/jbc.m104121200

Kumar, V. D., Vijay-Kumar, S., Krishnan, A., Duda, T., and Sharma, R. K. (1999). A second calcium regulator of rod outer segment membrane guanylate cyclase, ROS-GC1: neurocalcin. Biochemistry 38, 12614-12620. doi: 10.1021/bi9 $90851 n$

Lange, C., Duda, T., Beyermann, M., Sharma, R. K., and Koch, K. W. (1999). Regions in vertebrate photoreceptor guanylyl cyclase ROS-GC1 involved in $\mathrm{Ca} 2+-$ dependent regulation by guanyly cyclase-activating protein GCAP-1. FEBS Lett. 460, 27-31. doi: 10.1016/s0014-5793(99)01312-5

Leibovic, K. N., and Bandarchi, J. (1997a). Phototransduction and calcium exchange along the length of the retinal rod outer segment. Neuroreport 8 , 1295-1300.

Leibovic, K. N., and Bandarchi, J. (1997b). Effects of light and temperature on the response gradient of retinal rod outer segments. Brain Res. 750, 321-324. doi: 10.1016/S0006-8993(96)01357-1

Li, C., Pan, W., Braunewell, K. H., and Ames, J. B. (2011). Structural analysis of $\mathrm{Mg}^{2+}$ and $\mathrm{Ca}^{2+}$ binding, myristoylation and dimerization of the neuronal calcium sensor and visinin-like protein 1 (VILIP-1). J. Biol. Chem. 286, 6354-6366. doi: 10.1074/jbc.M110.173724

Liebman, P. A., and Entine, G. (1974). Lateral diffusion of visual pigment in photoreceptor disk membranes. Science 185, 457-459. doi: 10.1126/science.185. 4149.457

Lim, S., Dizhoor, A. M., and Ames, J. B. (2014). Structural diversity of neuronal calcium sensor proteins and insights for activation of retinal guanylyl cyclase by GCAP1. Front. Mol. Neurosci. 7:19. doi: 10.3389/fnmol.2014. 00019

Lim, S., Peshenko, I., Dizhoor, A., and Ames, J. B. (2009). Effects of $\mathrm{Ca}^{2+}$, $\mathrm{Mg}^{2+}$ and myristoylation on guanylyl cyclase activating protein 1 structure and stability. Biochemistry 48, 850-862. doi: 10.1021/bi801897p

Lim, S., Strahl, T., Thorner, J., and Ames, J. B. (2011). Structure of a $\mathrm{Ca}^{2+}$ myristoyl switch protein that controls activation of a phosphatidylinositol 4- kinase in fission yeast. J. Biol. Chem. 286, 12565-12577. doi: 10.1074/jbc.m110. 208868

Liu, H., Seno, K., and Hayashi, F. (2003). Active transducin alpha subunit carries PDE6 to detergent-resistant membranes in rod photoreceptor outer segments. Biochem. Biophys. Res. Commun. 303, 19-23. doi: 10.1016/s0006$291 \times(03) 00284-5$

Lobanova, E. S., Finkelstein, S., Song, H., Tsang, S. H., Chen, C. K., Sokolov, M., et al. (2007). Transducin translocation in rods is triggered by saturation of the GTPase-activating complex. J. Neurosci. 27, 1151-1160. doi: 10.1523/jneurosci. 5010-06.2007

Lowe, D. G. Dizhoor, A. M., Liu, K., Gu, Q., Spencer, M., Laura, R., et al. (1995). Cloning and expression of a second photoreceptor-specific membrane retina guanylyl cyclase (RetGC), RetGC-2. Proc. Natl. Acad. Sci. U S A 92, 5535-5539. doi: 10.1073/pnas.92.12.5535

Luo, D. G., Xue, T., and Yau, K. W. (2008). How vision begins: an odyssey. Proc. Natl. Acad. Sci. U S A 105, 9855-9862. doi: 10.1073/pnas.0708405105

Ma, X., Beuve, A., and van den Akker, F. (2010). Crystal structure of the signaling helix coiled-coil domain of the betal subunit of the soluble guanylyl cyclase. BMC Struct. Biol. 10:2. doi: 10.1186/1472-6807-10-2

Maeda, T., Imanishi, Y., and Palczewski, K. (2003). Rhodopsin phosphorylation: 30 years later. Progr. Ret. Eye Res. 22, 417-434. doi: 10.1016/s1350-9462(03) 00017-x

Makino, C. L., Dodd, R. L., Chen, J., Burns, M. E., Roca, A., Simon, M. I., et al. (2004). Recoverin regulates light-dependent phosphodiesterase activity in retinal rods. J. Gen. Physiol. 123, 729-741. doi: 10.1085/jgp. 200308994

Makino, C. L., Wen, X. H., Olshevskaya, E. V., Peshenko, I. V., Savchenko, A. B., and Dizhoor, A. M. (2012). Enzymatic relay mechanism stimulates cyclic GMP synthesis in rod photoresponse: biochemical and physiological study in guanyly cyclase activating protein 1 knockout mice. PLoS One. 7:e47637. doi: 10.1371/journal.pone.0047637

Margulis, A., Goraczniak, R. M., Duda, T., Sharma, R. K., and Sitaramayya, A. (1993). Structural and biochemical identity of retinal rod outer segment membrane guanylate cyclase. Biochem. Biophys. Res. Commun. 194, 855-861. doi: 10.1006/bbrc.1993.1900

Marino, V., Astegno, A., Pedroni, M., Piccinelli, F., and Dell'Orco, D. (2014). Nanodevice-induced conformational and functional changes in a prototypical calcium sensor protein. Nanoscale 6, 412-423. doi: 10.1039/c3nro $4978 \mathrm{~g}$

Marino, V., Sulmann, S., Koch, K. W., and Dell'Orco, D. (2015). Structural effects of $\mathrm{Mg}^{2+}$ on the regulatory states of three neuronal calcium sensors operating in vertebrate phototransduction. Biochim. Biophys. Acta 1853, 2055-2065. doi: 10. 1016/j.bbamcr.2014.10.026

Martin, R. E., Elliott, M. H., Brush, R. S., and Anderson, R. E. (2005). Detailed characterization of the lipid composition of detergent-resistant membranes from photoreceptor rod outer segment membranes. Invest. Ophthalmol. Vis. Sci. 46, 1147-1154. doi: 10.1167/iovs.04-1207

Mazzolini, M., Facchetti, G., Andolfi, L., Zaccaria, P. R., Tuccio, S., Treu, J., et al. (2015). The phototransduction machinery in the rod outer segment has a strong efficacy gradient. Proc. Natl. Acad. Sci. U S A 112, E2715-E2724. doi: 10. 1073/pnas.1423162112

Meador, W. E., Means, A. R., and Quiocho, F. A. (1993). Modulation of calmodulin plasticity in molecular recognition on the basis of x-ray structures. Science 262, 1718-1721. doi: 10.1126/science.8259515

Mendez, A., Burns, M. E., Sokal, I., Dizhoor, A. M., Baehr, W., Palczewski, K., et al. (2001). Role of guanylate cyclase-activating proteins (GCAPs) in setting the flash sensitivity of rod photoreceptors. Proc. Natl. Acad. Sci. U S A 98, 9948-9953. doi: 10.3410/f.1001761.6254

Michalakis, S., Zong, X., Becirovic, E., Hammelmann, V., Wein, T., Wanner, K. T., et al. (2011). The glutamic acid-rich protein is a gating inhibitor of cyclic nucleotide-gated channels. J. Neurosci. 31, 133-141. doi: 10.1523/jneurosci. 4735-10.2011

Molday, L. L., Djajadi, H., Yan, P., Szczygiel, L., Boye, S. L., Chiodo, V. A., et al. (2013). RD3 gene delivery restores guanylate cyclase localization and rescues photoreceptors in the Rd3 mouse model of Leber congenital amaurosis 12 . Hum. Mol. Genet. 22, 3894-3905. doi: 10.1093/hmg/ddt244

Nair, K. S., Balasubramanian, N., and Slepak, V. Z. (2002). Signal-dependent translocation of transducin, RGS9-1-Gbeta5L complex and arrestin to 
detergent-resistant membrane rafts in photoreceptors. Curr.Biol. 12, 421-425 doi: 10.1016/s0960-9822(02)00691-7

O'Callaghan, D. W., Tepikin, A. V., and Burgoyne, R. D. (2003). Dynamics and calcium sensitivity of the Ca2+/myristoyl switch protein hippocalcin in living cells. J. Cell Beiol. 163, 715-721. doi: 10.1083/jcb.200 306042

Orban, T., Huang, C. C., Homan, K. T., Jastrzebska, B., Tesmer, J. J. G., and Palczewski, K. (2012). Substrate-induced changes in the dynamics of rhodopsin kinase (G protein-coupled receptor kinase 1). Biochemistry 51, 3404-3411.

Palczewski, K. (2012). Chemistry and biology of vision. J. Biol. Chem. 287, 1612-1619. doi: 10.1074/jbc.R111.301150

Palczewski, K., Kumasaka, T., Hori, T., Behnke, C. A., Motoshima, H., Fox, B. A., et al. (2000). Crystal structure of rhodopsin: a $G$ protein-coupled receptor. Science 289, 739-745. doi: 10.1126/science.289.5480.739

Palczewski, K., Subbaraya, I., Gorczyca, W. A., Helekar, B. S., Ruiz, C. C., Ohguro, H., et al. (1994). Molecular cloning and characterization of retinal photoreceptor guanylyl cyclase-activating protein. Neuron 13, 395-404. doi: 10. 1016/0896-6273(94)90355-7

Pearring, J. N., Salinas, R. Y., Baker, S. A., and Arshavsky, V. Y. (2013). Protein sorting, targeting and trafficking in photoreceptor cells. Prog. Retin. Eye Res. 36, 24-51. doi: 10.1016/j.preteyeres.2013.03.002

Pentia, D. C., Hosier, S., and Cote, R. H. (2006). The glutamic acid-rich protein2 (GARP2) is a high affinity rod photoreceptor phosphodiesterase (PDE6)binding protein that modulates its catalytic properties. J. Biol. Chem. 281, 5500-5505. doi: 10.1074/jbc.m507488200

Peshenko, I. V., and Dizhoor, A. M. (2006). $\mathrm{Ca}^{2+}$ and $\mathrm{Mg}^{2+}$ binding properties of GCAP-1. Evidence that $\mathrm{Mg}^{2+}$-bound form is the physiological activator of photoreceptor guanylyl cyclase. J. Biol. Chem. 281, 23830-23841. doi: 10. 1074/jbc.m600257200

Peshenko, I. V., Olshevskaya, E. V., and Dizhoor, A. M. (2015a). Evaluating the role of retinal membrane guanylyl cyclase 1 (RetGC1) domains in binding guanylyl cyclase-activating proteins (GCAPs). J. Biol. Chem. 290, 6913-6924. doi: $10.1074 /$ jbc.M114.629642

Peshenko, I. V., Olshevskaya, E. V., and Dizhoor, A. M. (2015b). Dimerization domain of retinal membrane guanylyl cyclase 1 (RetGC1) is an essential part of guanylyl cyclase-activating protein (GCAP) binding interface. J. Biol. Chem. 290, 19584-19596. doi: 10.1074/jbc.m115.661371

Peshenko, I. V., Olshevskaya, E. V., Azadi, S., Molday, L. L., Molday, R. S., and Dizhoor, A. M. (2011a). Retinal degeneration 3 (RD3) protein inhibits catalytic activity of retinal membrane guanylyl cyclase (RetGC) and its stimulation by activating proteins. Biochemistry 50, 9511-9519. doi: 10.1021/bi201342b

Peshenko, I. V., Olshevskaya, E. V., Savchenko, A. B., Karan, S., Palczewski, K., Baehr, W., et al. (2011b). Enzymatic properties and regulation of the native isozymes of retinal membrane guanylyl cyclase (RetGC) from mouse photoreceptors. Biochemistry 50, 5590-5600. doi: 10.1021/ bi200491b

Peshenko, I. V., Moiseyev, G. P., Olshevskaya, E. V., and Dizhoor, A. M. (2004). Factors that determine $\mathrm{Ca}^{2+}$ sensitivity of photoreceptor guanylyl cyclase. Kinetic analysis of the interaction between the $\mathrm{Ca}^{2+}$-bound and the $\mathrm{Ca}^{2+}$-free guanylyl cyclase activating proteins (GCAPs) and recombinant photoreceptor guanylyl cyclase 1 (RetGC-1). Biochemistry 43, 13796-13804.

Poetsch, A., Molday, L. L., and Molday, R. S. (2001). The cGMP-gated channel and related glutamic acid-rich proteins interact with peripherin-2 at the rim region of rod photoreceptor disc membranes. J. Biol. Chem. 276, 48009-48016. doi: 10. 1074/jbc.M108941200

Poo, M., and Cone, R. A. (1974). Lateral diffusion of rhodopsin in the photoreceptor membrane. Nature 247, 438-441. doi: 10.1038/247438a0

Preising, M. N., Hausotter-Will, N., Solbach, M. C., Friedburg, C., Rüschendorf, F., and Lorenz, B. (2012). Mutations in RD3 are associated with an extremely rare and severe form of early onset retinal dystrophy. Invest. Ophthalmol. Vis. Sci. 53, 3463-3472. doi: 10.1167/iovs.12-9519

Premont, R. T., and Gainetdinov, R. R. (2007). Physiological roles of G proteincoupled receptor kinases and arrestins. Annu. Rev. Physiol. 69, 511-534. doi: 10. 1146/annurev.physiol.69.022405.154731

Pugh, E. N. Jr and Lamb, T. D. (2000). "Phototransduction in vertebrate rods and cones: molecular mechanisms of amplification, recovery and light adaptation," in Handbook of Biological Physics Elsevier Science BV, eds D. G. Stavenga, W. J. DeGrip, and E. N. Pugh Jr. (New york, NY: Elsevier Science), 183-255.
Pulvermüller, A., Giessl, A., Heck, M., Wottrich, R., Schmitt, A., Ernst, O. P., et al. (2002). Calcium-dependent assembly of centrin-G-protein complex in photoreceptor cells. Mol. Cell. Biol. 22, 2194-2203. doi: 10.1128/mcb.22.7.21942203.2002

Pulvermüller, A., Palczewski, K., and Hofmann, K. P. (1993). Interaction bewteen photoactivated rhodopsin and ist kinase: stability and kinetics of complex formation. Biochemistry 32, 14082-14088. doi: 10.1021/bi0021 $4 \mathrm{a} 002$

Ramamurthy, V., Tucker, C., Wilkie, S., Daggett, V., Hunt, D., and Hurley, J. B. (2001). Interactions within the coiled-coil domain of RetGC-1 guanlyly cyclase are optimized for regulation rather than for high affinity. J. Biol. Chem. 276, 26218-26229. doi: 10.1074/jbc.m010495200

Rätscho, N., Scholten, A., and Koch, K. W. (2009). Expression profiles of three novel sensory guanylate cyclases and guanylate cyclase-activating proteins in the zebrafish retina. Biochim. Biophys. Acta 1793, 1110-1114. doi: 10.1016/j. bbamcr.2008.12.021

Robin, J., Brauer, J., Sulmann, S., Marino, V., Dell'Orco, D., Lienau, C., et al. (2015). Differential nanosecond protein dynamics in homologous calcium sensors. ACS Chem. Biol. 10, 2344-2352. doi: 10.1021/acschembio.5b00278

Roof, D. J., and Heuser, J. E. (1982). Surfaces of rod photoreceptor disk membranes: integral membrane components. J. Cell. Biol. 95, 487-500. doi: 10. 1083/jcb.95.2.487

Rosenzweig, D. H., Nair, K. S., Levay, K., Peshenko, I. V., Crabb, J. W., Dizhoor, A. M., et al. (2009). Interaction of retinal guanylate cyclase with the alpha subunit of transducin: potential role in transducin localization. Biochem. J. 417, 803-812. doi: 10.1042/bj20081513

Saibil, H., Chabre, M., and Worcester, D. (1976). Neutron diffraction studies of retinal rod outer segment membranes. Nature 262, 266-270. doi: 10. $1038 / 262266 \mathrm{a} 0$

Sakurai, K., Chen, J., Khani, S. C., and Kefalov, V. J. (2015). Regulation of mammalian cone phototransduction by recoverin and rhodopsin kinase. J. Biol. Chem. 290, 9239-9250. doi: 10.1074/jbc.m115.639591

Sakurai, K., Young, J. E., Kefalov, V. J., and Khani, S. C. (2011). Variation in rhodopsin kinase expression alters the dim flash response shut off and the light adaptation in rod photoreceptors. Invest. Ophthalmol. Vis. Sci. 29, 6793-6800. doi: 10.1167/iovs.11-7158

Sarfare, S., McKeown, A. S., Messinger, J., Rubin, G., Wei, H., Kraft, T. W., et al. (2014). Overexpression of rod photoreceptor glutamic acid rich protein 2 (GARP2) increases gain and slows recovery in mouse retina. Cell Commun. Signal. 12: 67. doi: 10.1186/s12964-014-0067-5

Schnapf, J. L. (1983). Dependence of the single photon response on longitudinal position of absorption in toad rod outer segments. J. Physiol. 343, 147-159. doi: 10.1113/jphysiol.1983.sp014886

Scholten, A., and Koch, K. W. (2011). Differential calcium signaling by cone specific guanylate cyclase-activating proteins from the zebrafish retina. PLoS One 6:e23117. doi: 10.1371/journal.pone.0023117

Schöneberg, J., Heck, M., Hofmann, K. P., and Noé, F. (2014). Explicit spatiotemporal simulation of receptor-G protein coupling in rod cell disk membranes. Biophys. J. 107, 1042-1053. doi: 10.1016/j.bpj.2014. 05.050

Schöneberg, J., Heck, M., Hofmann, K. P., and Noé, F. (2015). Response to comment "Transient complexes between dark rhodopsin and transducin: circumstantial evidence or physiological necessity?" by D. Dell'Orco and K.-W. Koch. Biophys. J. 108, 778-779. doi: 10.1016/j.bpj.2014.12.030

Schrem, A., Lange, C., Beyermann, M., and Koch, K.-W. (1999). Identification of a domain in guanylyl cyclase-activating protein 1 that interacts with a complex of guanylyl cyclase and tubulin in photoreceptors. J. Biol. Chem. 274, 6244-6249. doi: $10.1074 /$ jbc.274.10.6244

Schwarzer, A., Schauf, H., and Bauer, P. J. (2000). Binding of the cGMP-gated channel to the Na/Ca-K exchanger in rod photoreceptors. J. Biol. Chem. 275, 13448-13454. doi: 10.1074/jbc.275.18.13448

Senin, I. I., Fischer, T., Komolov, K. E., Zinchenko, D. V., and Philippov, P. P., and Koch, K.-W. (2002a). $\mathrm{Ca}^{2+}$-myristoyl switch in the neuronal calcium sensor recoverin requires different functions of $\mathrm{Ca}^{2+}$-binding sites. J. Biol. Chem. 277, 50365-50372. doi: 10.1074/jbc.m204338200

Senin, I. I., Koch, K. W., Akhtar, M., and Philippov, P. P. (2002b). Ca ${ }^{2+}$-dependent control of rhodopsin phosphorylation: recoverin and rhodopsin kinase. $A d v$. Exp. Med. Biol. 514, 69-99. doi: 10.1007/978-1-4615-0121-3_5 
Senin, I. I., Hoeppner-Heitmann, D., Polkovnikova, O. O., Churumova, V. A., Tikhomirova, N. K., Philippov, P. P., et al. (2004). Recoverin and rhodopsin kinase activity in detergent-resistant membrane rafts from rod outer segments. J. Biol. Chem. 279, 48647-48653. doi: 10.1074/jbc.m402516200

Senin, I. I., Vaganova, S. A., Weiergräber, O. H., Ergonov, N. S., Philippov, P. P., and Koch, K.-W. (2003). Functional restoration of the $\mathrm{Ca}^{2+}$-myristoyl switch in a recoverin mutant. J. Mol. Biol. 330, 409-418. doi: 10.1016/s00222836(03)00581-3

Senin, I. I., Zargarov, A. A., Alekseev, A. M., Gorodovikova, E. N., Lipkin, V. M., and Philippov, P. P. (1995). N-myristoylation of recoverin enhances its efficiency as an inhibitor of rhodopsin kinase. FEBS Lett. 376, 87-90. doi: 10. 1016/0014-5793(95)01187-2

Seno, K., Kishimoto, M., Abe, M., Higuchi, Y., Mieda, M., Owada, Y., et al. (2001). Light- and guanosine 5'-3-O-(thio)triphosphate-sensitive localization of a $\mathrm{G}$ protein and its effector on detergent-resistant membrane rafts in rod photoreceptor outer segments. J. Biol. Chem. 276, 20813-20816. doi: 10. 1074/jbc.c100032200

Shen, L., Caruso, G., Bisegna, P., Andreucci, D., Gurevich, V. V., Hamm, H. E., et al. (2010). Dynamics of mouse rod phototransduction and its sensitivity to variation of key parameters. IET Syst. Biol. 4, 12-32. doi: 10.1049/iet-syb.2008. 0154

Shichi, H., and Williams, T. C. (1979). Rhodopsin phosphorylation suggests biochemical heterogeneities of retinal rod disks. J. Supramol. Struct. 12, 419-424. doi: 10.1002/jss.400120402

Singh, P., Wang, B., Maeda, T., Palczewski, K., and Tesmer, J. J. G. (2008). Structures of rhodopsin kinase in different ligand states reveal key elements involved in G proiten-coupled receptor kinase activation. J. Biol. Chem. 283, 14053-14062. doi: 10.3410/f.1103994.561150

Sokal, I., Haeseleer, F., Arendt, A., Adman, E. T., Hargrave, P. A., and Palczewski, K. (1999a). Identification of a guanylyl cyclase-activating protein-binding site within the catalytic domain of retinal guanylyl cyclase 1. Biochemistry 38, 1387-1393. doi: 10.1021/bi982512k

Sokal, I., Otto-Bruc, A. E., Surgucheva, I., Verlinde, C. L. M., Wang, C. K., Baehr, W., et al. (1999b). Conformational changes in guanylyl cyclase-activating protein 1 (GCAP1) and its tryptophan mutants as a function of calcium concentration. J. Biol. Chem. 274, 19829-19837. doi: 10.1074/jbc.274.28.19829

Sokolov, M., Lyubarsky, A. L., Strissel, K. J., Savchenko, A. B., Govardovskii, V. I., Pugh, E. N., et al. (2002). Massive light-driven translocation of transducin between the two major compartments of rod cells: a novel mechanism of light adaptation. Neuron 28, 95-106. doi: 10.3410/f.1005371.64305

Sommer, M. E., Hofmann, K. P., and Heck, M. (2014). Not just signal shutoff: the protective role of arrestin-1 in rod cells. Handb. Exp. Pharmacol. 219, 101-116. doi: 10.1007/978-3-642-41199-1_5

Stephen, R., Bereta, G., Golczak, M., Palczewski, K., and Sousa, M. C. (2007). Stabilizing function for myristoyl group revealed by the crystal structure of a neuronal calcium sensor, guanylate cyclase-activating protein 1. Structure 15, 1392-1402. doi: 10.1016/j.str.2007.09.013

Stryer, L. (1991). Visual excitation and recovery. J. Biol. Chem. 266, 10711-10714.

Sugimoto, Y., Yatsunami, K., Tsujimoto, M., Khorana, H. G., and Ichikawa, A. (1991). The amino acid sequence of a glutamic acid-rich protein from bovine retina as deduced from the cDNA sequence. Proc. Natl. Acad. Sci. U S A 88, 3116-3119. doi: 10.1073/pnas.88.8.3116

Sulmann, S. Vocke, F. Scholten, A. and Koch, K. W. (2015). Retina specific GCAPs in zebrafish acquire functional selectivity in $\mathrm{Ca}^{2+}$-sensing by myristoylation and $\mathrm{Mg}^{2+}$-binding. Sci. Rep. 5:11228. doi: 10.1038/srep11228

Sulmann, S., Dell'Orco, D., Marino, V., Behnen, P., and Koch, K.-W. (2014). Conformational changes in calcium-sensor proteins under molecular crowding conditions. Chemistry Eur. J. 20, 6756-6762. doi: 10.1002/chem.201402146

Tanaka, T., Ames, J. B., Harvey, T. S., Stryer, L., and Ikura, M. (1995). Sequestration of the membrane-targeting myristoyl group of recoverin in the calcium-free state. Nature 376, 444-447. doi: 10.1038/376444a0

Venkataraman, V., Duda, T., Ravichandran, S., and Sharma, R. K. (2008). Neurocalcin delta Modulation of ROS-GC1, a New Model of $\mathrm{Ca}^{2+}$ Signaling. Biochemistry 47, 6590-6601. doi: 10.1021/bi800394s
Venkataraman, V., Duda, T., Vardi, N., Koch, K.-W., and Sharma, R. K. (2003). Calcium-modulated guanylate cyclase (ROS-GC1) transduction machinery in the photoreceptor-bipolar region. Biochemistry 42, 5640-5648. doi: 10 . 1021/bi034025x

Wang, J., and Deretic, D. (2014). Molecular complexes that direct rhodopsin transport to primary cilia. Prog. Retin. Eye Res. 38, 1-19. doi: 10.1016/j. preteyeres.2013.08.004

Weiergräber, O., Senin, I. I., Zernii, E. Y., Churumova, V. A., Kovaleva, N. A., Nazipova, A. A., et al. (2006). Tuning of a neuronal calcium sensor. J. Biol. Chem. 281, 37594-37602. doi: 10.1074/jbc.M603700200

Weiergräber, O. H., Senin, I. I., Philippov, P. P., and Granzin, J. and Koch, K. W. (2003). Impact of $\mathrm{N}$-terminal myristoylation on the $\mathrm{Ca}^{2+}$-dependent conformational transition in recoverin. J. Biol. Chem. 278, 22972-22979. doi: $10.1074 /$ jbc.m300447200

Weitz, D., Ficek, N., Kremmer, E., Bauer, P. J., and Kaupp, U. B. (2002). Subunit stoichiometry of the CNG channel of rod photoreceptors. Neuron 36, 881-889. doi: 10.1016/s0896-6273(02)01098-x

Wen, X. H., Dizhoor, A. M., and Makino, C. L. (2014). Membrane guanylyl cyclase complexes shape the photoresponses of retinal rods and cones. Front. Mol. Neurosci. 7:45. doi: 10.3389/fnmol.2014.00045

Wen, X. H., Duda, T., Pertzev, A., Venkataraman, V., Makino, C. L., and Sharma, R. K. (2012). S100B serves as a $\mathrm{Ca}^{2+}$ sensor for ROS-GC1 guanylate cyclase in cones but not in rods of the murine retina. Cell. Physiol. Biochem. 29, 417-430. doi: 10.1159/000338496

Wensel, T. G. (2008). Signal transducing membrane complexes of photoreceptor outer segments. Vision Res. 48, 2052-2061. doi: 10.1016/j.visres.2008.03.010

Whited, A. M., and Park, P. S. (2015). Nanodomain organization of rhodopsin in native human and murine rod outer segment disc membranes. Biochim. Biophys. Acta. 1848, 26-34. doi: 10.1016/j.bbamem.2014.10.007

Young, R. W. (1967). The renewal of photoreceptor cell outer segments. J. Cell. Biol. 33, 61-72. doi: 10.1083/jcb.33.1.61

Zägel, P., Dell'Orco, D., and Koch, K.-W. (2013). The dimerization domain in outer segment guanylate cyclase isa Ca2+-sensitive control switch module. Biochemistry 52, 5065-5074. doi: 10.1021/bi400288p

Zernii, E., Komolov, K., Permyakov, S., Kolpakova, T., Dell'Orco, D., Poetzsch, A., et al. (2011). Involvement of recoverin C-terminal segment in recognition of the target enzyme rhodopsin kinase. Biochem. J. 435, 441-450. doi: 10. 1042/bj20110013

Zhang, Y., Molday, L. L., Molday, R. S., Sarfare, S. S., Woodruff, M. L., Fain, G. L., et al. (2009). Knockout of GARPs and the $\beta$-subunit of the rod cGMP-gated channel disrupts disk morphogenesis and rod outer segment structural integrity. J. Cell Sci. 122, 1192-1200. doi: 10.1242/jcs. 042531

Zheng, J., Trudeau, M. C. and Zagotta, W. N. (2002). Rod cyclic nucleotidegated channels have a stoichiometry of three CNGA1 subunits and one CNGB1 subunit. Neuron 36, 891-896. doi: 10.1016/s0896-6273(02) 01099-1

Zozulya, S., and Stryer, L. (1992). Calcium-myristoyl protein switch. Proc. Natl. Acad. Sci. U S A 89, 11569-11573. doi: 10.1073/pnas.89.23.11569

Zulliger, R., Naash, M. I., Rajala, R. V., Molday, R. S., and Azadi, S. (2015). Impaired association of retinal degeneration-3 with guanylate cyclase-1 and guanylate cyclase-activating protein-1 leads to leber congenital amaurosis-1. J. Biol. Chem. 290, 3488-3499. doi: 10.1074/jbc.m114.616656

Conflict of Interest Statement: The authors declare that the research was conducted in the absence of any commercial or financial relationships that could be construed as a potential conflict of interest.

Copyright (๑) 2015 Koch and Dell'Orco. This is an open-access article distributed under the terms of the Creative Commons Attribution License (CC BY). The use, distribution and reproduction in other forums is permitted, provided the original author(s) or licensor are credited and that the original publication in this journal is cited, in accordance with accepted academic practice. No use, distribution or reproduction is permitted which does not comply with these terms. 